\title{
原
}

犬歯の舌面傾斜が岨嚼系に及ぼす影響について

\author{
篠ヶ谷 龍 哉

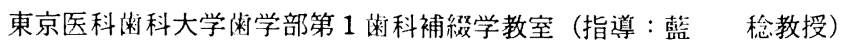

(1984年12月 20 日 受付)

\section{Effect of Experimental Cuspid Rise on Masticatory System}

\begin{abstract}
Tatsuya Shinogaya
The First Department of Prosthodontics, Faculty of Dentistry, Tokyo Medical and Dental University

(Director: Prof. Minoru Ai)
\end{abstract}

\begin{abstract}
The five-week progressive changes in the canine displacement in two directions of bucco-lingual and axial and the masticatory movement during gum chewing in the frontal plane were measured using a non-contact sensor system and SAPHON VISI-TRAINER on six subjects with the lingual incline of the canine by overlay ten degrees steeper. The displacement of the canine in the bucco-apex direction was almost straight loading from the lingual side. In five of the six subjects, the length of the outward path gradually increased with time after the overlay insertion, reaching the peak in 1 or 2 weeks, and after the overlay removal returned to almost the same value as before the overlay insertion. The progressive changes in the horizontal width of the intercuspal position showed a contrary tendency. Statistically, a close correlation between the canine displacement and the chewing cycle was found.
\end{abstract}

\section{I . 粕言}

下顎の滑走運動の際，歯列のどの部位がどのよ らに接触し運動を誘導するかは顎口腔系の機能に とって重要であり，咬合診断や補綴による咬合再 構成において大きな問題となるところである。側 方滑走運動の場合，大臼雨部の強い接触は筋や顎 関節また歯周組織にとって有害に働く咬頭干渉と される1 3) のに対して，犬歯や小臼歯の接触は下 顎の誘導部として極めて妥当なものとされてい る。 D'Amicot) は人類学的見地から犬歯の特異 性を指摘し, Guichet ${ }^{5)}$ は形態学的考察により犬 歯誘導の妥当性を主張している。しかし，その根 拠はあまり明確ではない。一方，下顎を誘導する
部位の傾斜の程度については全く解明されて扣ら ず, 最近になってようやく機能面からの追究が行 われるようになった6,7)。

著者は,こらした下顎運動に打ける歯の誘導の ハカニズムを検討するものの一環として本研究を 計画した。すなわち，犬歯誘導咬合および犬歯を 含む group-functioned 咬合を有する被験者につ いて上顎犬歯を対象としてその舌面傾 斜を急に し，その時に生ずる反応として荷重時の歯の変 位, 咀嚼運動路の变化を経時的に測定し, 考察を 加えることにした。

\section{II. 研究方法}

\section{1. 被験者および被験苗}


表 1 被験者および被験㢼

\begin{tabular}{|c|c|c|c|c|}
\hline \multirow{2}{*}{ 被験者 } & \multirow{2}{*}{ 年粎令 } & \multicolumn{2}{|c|}{ 側方位での歯の接触状態 } & \multirow{2}{*}{ 口腔状態 } \\
\hline & & 左側方位 & 右側方位 & \\
\hline \multirow{2}{*}{ A } & \multirow{2}{*}{27} & 3 & (3) & \multirow{2}{*}{ 特記事項なし } \\
\hline & & 3 & 3 & \\
\hline \multirow{2}{*}{ B } & \multirow{2}{*}{28} & 31 & (3) & \multirow{2}{*}{$\begin{array}{l}\text { (5) } 6(7): \mathrm{Br} \\
6 \mathrm{l}: \mathrm{MT}\end{array}$} \\
\hline & & 3 & $\longdiv { 3 }$ & \\
\hline \multirow{2}{*}{ C } & \multirow{2}{*}{30} & (3) & 3 & \multirow{2}{*}{$\stackrel{(5) 67}{4}: \mathrm{Br}$} \\
\hline & & 3 & 3 & \\
\hline \multirow{2}{*}{$\mathrm{D}$} & \multirow{2}{*}{23} & (3) & 3 & \multirow{2}{*}{ 特記事項なし } \\
\hline & & 3 & 3 & \\
\hline \multirow{2}{*}{$E$} & \multirow{2}{*}{20} & 3 & (3) & \multirow{2}{*}{ " } \\
\hline & & 3 & 3 & \\
\hline \multirow{2}{*}{$\mathrm{F}$} & \multirow{2}{*}{24} & 54 (3) & (3) 45 & \multirow{2}{*}{ " } \\
\hline & & 43 & 34 & \\
\hline
\end{tabular}

○は被験歯

被験者は, 顎口腔系に異常がみられず柬周組織 も臨床的に健全な20～30歳の成人男子 6 名である （表 1 ）。犬歯誘導咬合を有する被験者 $\mathrm{A} \sim \mathrm{E}$ では （図 1), 習慣性咀嚼側の上顎犬歯を被験歯とし, 反対側の上顎犬歯を対照歯として用いた。一方, group-functioned 咬合を有する被験者 Fでは両 側上顎犬歯を被験歯とした。

\section{2. 舌面装置の製作}

各被験者の上下顎歯列模型を半調節性咬合 器*1)に装着してから, 側方滑走運動させた時に その経路が切歯指導部で10度急になるよらに指導 板の傾きを調整した。ついで，それに合わせて被 験歯の舌面のレジンパターン*2)を採り,これを 白金加金*3)で鋳造して舌面装置とした。な打, 舌面装置を口腔内に装着した時に咬頭嵌合位の位 置は変わらないよらに調整した（図2）。

\section{3. 実験装置}

実験装置は歯の变位測定装置, 荷重計, 咬合力

*1) Denar Corp. Denar-Mark II System

*2) Kulzer 社 Palavit G

*3）石福金属興業 PGA-III

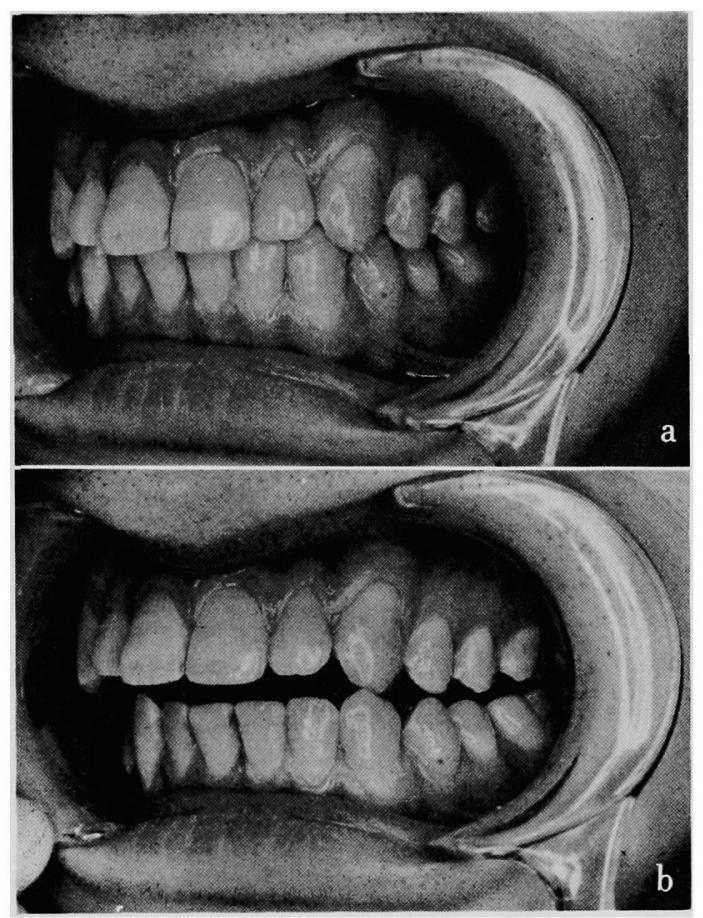

図 1 犬歯誘導咬合を有する被験者 $\mathrm{a}$ ：咬頭嵌合位

b : 左側方位

計*4) およびサホン・ビジトレーナー*5) より構成 される（図 3 )。変位測定装置からの出力は交流 ブリッジ回路と歪アンプ*6)により増幅し, X-Yレ コーダ*7) 上でモニターしつつデータレコーダ*8) に，また荷重計と咬合力計からの出力は同歪アン プで増幅し同様にレコーダに収録した。

1）曾の変位測定装置とその精度

歯の変位測定装置としてはらず電流効果を応用 した非接触微小変位センサを用いた。このセンサ は $1 \mathrm{mH}$ のチョークコイル*9) と直径 $5 \mathrm{~mm}$ のベー クライトコアからなるコイルセンサ（L）と, 直 径 $6 \mathrm{~mm}$, 厚さ $0.2 \mathrm{~mm}$, 重量 $0.1 \mathrm{~g}$ の鉄板のター ゲット（T）により構成されている。

\footnotetext{
*4) ST 研究所 LM 8F-30

*5）東京菌材社・佐藤医療電子製作所

*6) 三栄測器 動ひずみ増幅器 $6 \mathrm{M} 62$

*7）渡辺測器 X-Y レニーダ WX 441

*8）ソニーマグネスケール エルカセットデータレコーダ FE-3807W
} 

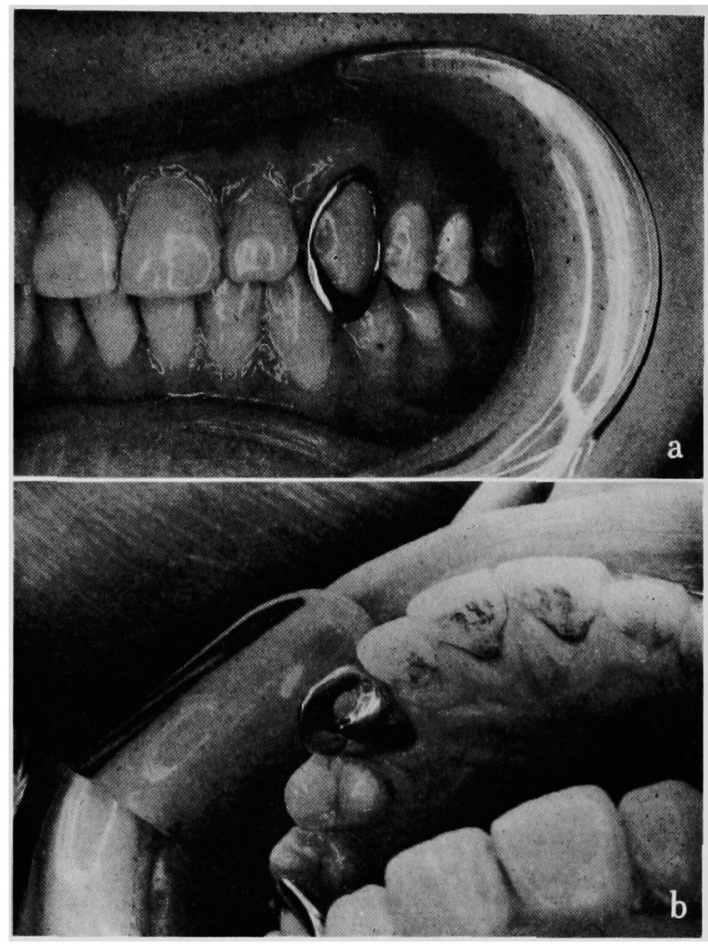

図 2 舌面装置

a ：煩側面観 b ：舌側面観（ミラ一使用）
本測定ではこのセンサを直角に 2 個用いたが， その精度についてはつぎのよらである。較正 器*10)でターゲットをX方向, あるいは Y方向に

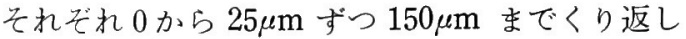
10 回移動させた時の出力誤差は $2 \%$ 以下（表 2 ）, また変位と出力の関係は直線性を示すが, その誤 差は $1 \%$ 以下であった（図 4 ）。

またターゲットをX方向あるいはY方向へ移 動させた時，2つのセンサからは各方向の出力と 同時にY方向あるいはX方向の出力も生じる。そ のため, X-Yレコーダ上に描かれる座標系には 歪が生じ（図 5 )，X軸，Y軸はそれぞれ $\theta \mathrm{X}, \theta_{\mathrm{Y}}$ 傾斜する。これらの值は平均約 2 度, 約 9 度でそ の䛊差はいずれも $1 \%$ 以下であった（表 3 ）。

こうした座標系の歪によって図 5 における距離 $\ell, \mathrm{X}$ 軸となす角度 $\theta$ の任意の経路 $\mathrm{OA}$ は, 距離 $\ell^{\prime}$, 角度 $\theta^{\prime}$ の $\mathrm{OA}^{\prime}$ となり, その場合の距離の絶 対詋差は 3〜8\%で， $\theta$ が大きいほど誤差も大き くなりまた角度の絶対誤差は約10\%であった。

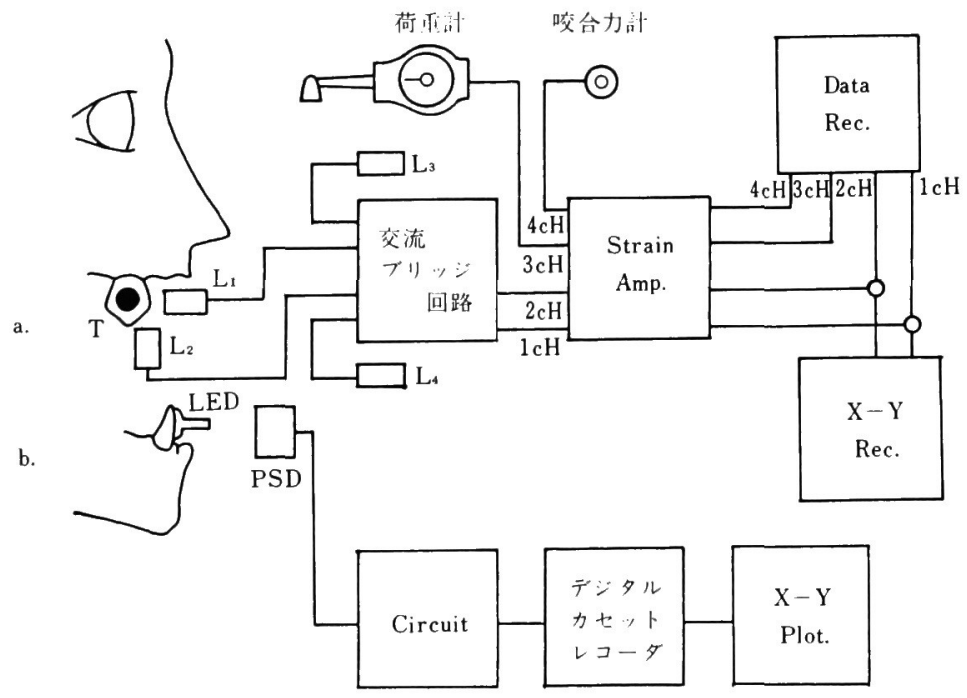

図 3 実験装置ブロック図
a：歯の変位側定
b：下顎運動路の記録
$\mathrm{L}_{1 \sim 4}$ : コイルセンサ
T：ターゲット

LED : 受光素子

*g） T. D. K. チョークコイル CSL-0609-102K

*10）三金工業 P.P.メタル 

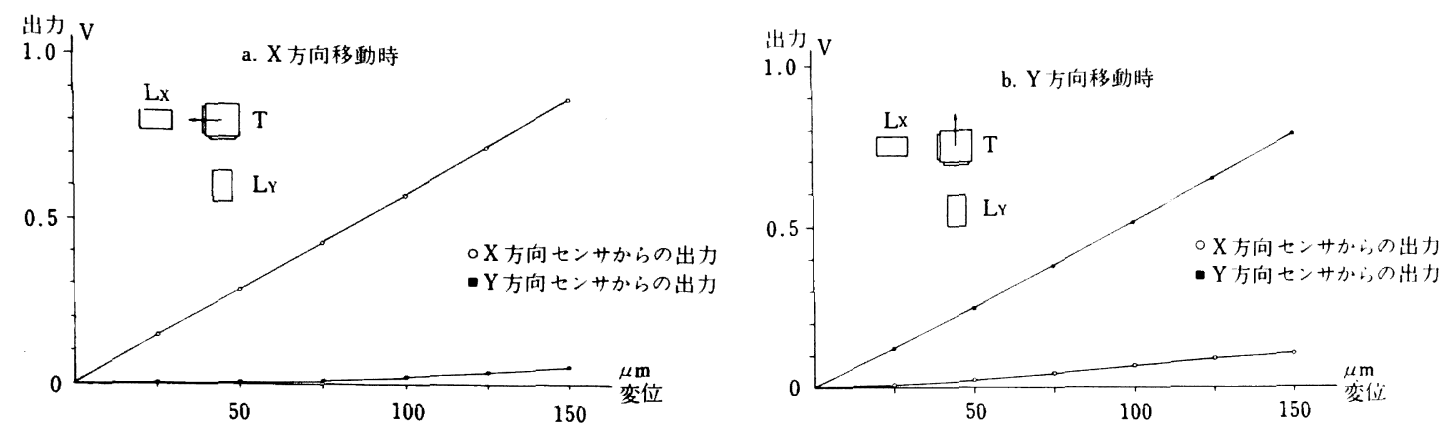

図 4 変位と出力の関係

$$
\begin{aligned}
& \mathrm{L}_{\mathrm{X}}: \mathrm{X} \text { 方向用コイルセンサ } \\
& \mathrm{L}_{\mathrm{Y}}: \mathrm{Y} \text { 方向用ュイルセンサ } \\
& \mathrm{T}: \text { ターゲット }
\end{aligned}
$$

表 2 ターゲットの各移動量における出力の誤差

\begin{tabular}{c|c|c|c|c|c|c}
\hline \hline 移 動 重 $(\mu \mathrm{m})$ & 25 & 50 & 75 & 100 & 125 & 150 \\
\hline $\mathrm{X}$ 方向センサからの出力の誤差 $(\%)$ & 1.57 & 1.31 & 1.81 & 1.53 & 1.59 & 1.14 \\
\hline $\mathrm{Y}$ 方向センサからの出力の誤差 $(\%)$ & 1.20 & 0.82 & 0.59 & 0.48 & 0.43 & 0.29
\end{tabular}

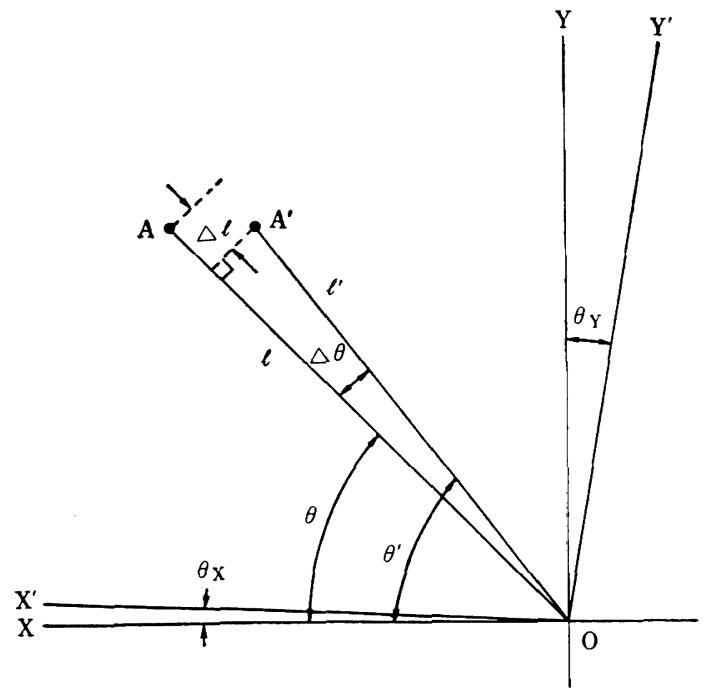

距離の絶対誤差 $=\Delta \ell / \ell \times 100(\%)$ 角度の絶対誤差 $=\triangle \theta / \theta \times 100(\%)$ 図 $5 \mathrm{X}$ 軸, $\mathrm{Y}$ 軸の歪に伴う誤差 $\mathrm{X}$ 軸, $\mathrm{Y}$ 軸の座標系の昰に伴い距離 $\ell$, 角度 $\theta$ の経路 $\mathrm{OA}$ は距離 $\ell^{\prime}$, 角度 $\theta^{\prime}$ の経路 $\mathrm{OA}^{\prime}$ に なる
百分率誤差 $=\sqrt{\sum_{\mathrm{i}=1}^{\mathrm{n}}\left(\overline{\mathrm{x}}-\mathrm{x}_{\mathrm{i}}\right)^{2}} / \mathrm{n} \overline{\mathrm{x}} \times 100, \overline{\mathrm{x}}=\sum_{\mathrm{i}=1}^{\mathrm{n}} \mathrm{x}_{\mathrm{i}} / \mathrm{n}$

表 3 ターゲットの各移動量におけるX軸, Y 軸の傾 斜とその誤差

\begin{tabular}{l|c|c|c|c|c|c}
\hline \hline $\begin{array}{c}\text { 移動 量 } \\
(\mu \mathrm{m})\end{array}$ & 25 & 50 & 75 & 100 & 125 & 150 \\
\hline$\theta_{\mathrm{X}}$ (度) & 1.86 & 2.14 & 2.14 & 2.13 & 2.11 & 2.10 \\
䛊差(\%) & 0.74 & 0.69 & 0.84 & 0.51 & 0.67 & 0.89 \\
\hline$\theta_{\mathrm{Y}}($ 度) & 9.17 & 8.84 & 8.63 & 8.50 & 8.41 & 8.31 \\
誤差 $(\%)$ & 0.91 & 0.76 & 0.94 & 0.81 & 0.63 & 0.87
\end{tabular}

2）荷重計および咬合力計

荷重計は Haldex の Tension gauge の板バネ にストレンゲージを貼付したものを用いた。荷重 計の先端にはレジンによる直径 $8 \mathrm{~mm}$ の底面をも つ円錐状の加重部を付加し（図 6-a)，これを被験 米舌面にあてて手指により500～700 g の荷重量を 加えた（以下，これを手指荷重とする）。また， 咬合力計の受圧部は直径 $8 \mathrm{~mm}$, 厚さ $2.5 \mathrm{~mm}$ で あるが(図 6-b)，これを $2 \sim 3 \mathrm{~kg}$ の出力が得ら 
れるように被験者に咬みしめを行わせた（以下， これを咬合荷重とする)。本咬合力計は容量 $30 \mathrm{~kg}$ で，この時の直線性の誤差は $0.5 \%$ ，ヒステリシ ス $1 \%$, 再現性 $0.5 \%$, 温度特性 $0.1 \% /{ }^{\circ} \mathrm{C}$ であ る。

\section{4. 装置の設定と固定}

1）設定

犬歯の変位測定は頓舌扐よび雨冠軸方向の 2 万 向で行ったが，歯冠軸の方向は歯列模型上で決定 乙，煩舌方向は歯冠軸を含み犬歯の近遠心と直角 をなす方向とした。まず一辺が $8 \mathrm{~mm}$ の立方体の

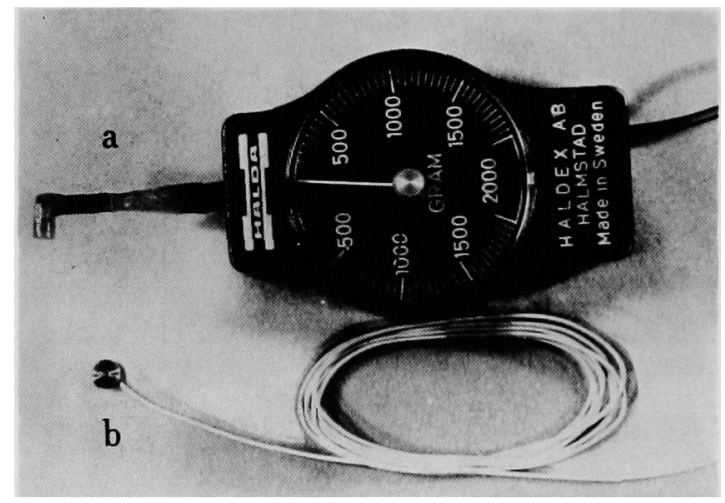

図 6 荷重計（a）括よび咬台力計（b)
レジンブロックの直交する 2 面にターゲットをシ アノアクリレート接着材を用いて貼付した。つい でターゲットを貼付した面が頉舌㧍よび歯冠軸方 向と一致するよう模型上でレジンブロックを犬歯 唇面の中央に即時重合レジンを用いて設定した (図 7)。な特, この位置は口腔内に常に正しく再 現されなければならないので，そのためのジグと して両隣在歯を含む設定用コアをレジンで作り用 いた。

歯の荷重には荷重計加重部および咬合力計受圧 部が保持できるようにレジンでアダプタを制作し た。これは犬歯の切縁を覆い, 荷重計加重部拉よ び咬合力計受圧部を受けるもので, 直径約 $8 \mathrm{~mm}$, 厚さ約 $1.5 \mathrm{~mm}$ とした（図 $7-\mathrm{a} ， \mathrm{~b}$ )。

コイル七ンサの設定には測定の対象となる雨と 同側の中切歯から反対側の犬歯をで前歯 4 歯を固 定源とする唇側メタルシーネを鋳造し*11)，これ にバーを介してセンサ用ハウジングを接続した。 八ウジングのターゲットに対する位置関係は，厚 さ $1.5 \mathrm{~mm} の \mathrm{~L}$ 字型スペーサを用いて決定した。 なお、メタルンーネについては側方滑走運動に対 する障害やセンサに対する影響がないことをあら かじめ確認した。
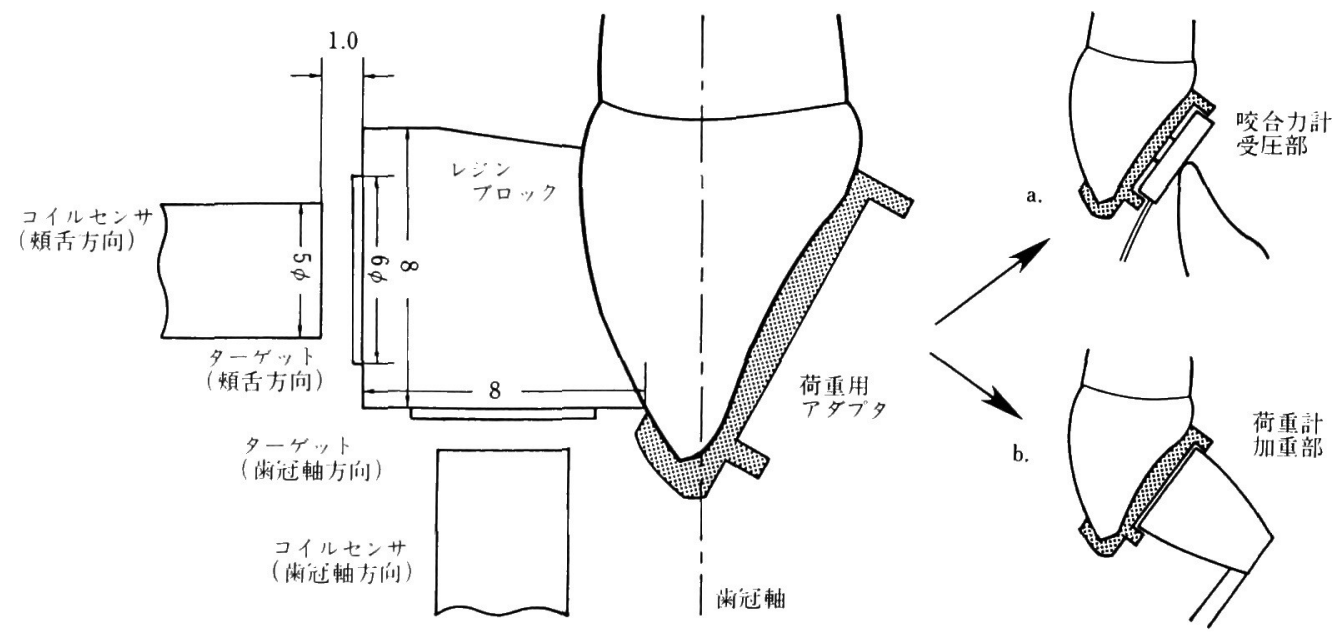

図7 装置 の 設 定

$\mathrm{a}$ ：咬合荷重時 $\mathrm{b}$ ：手指荷重時

*11) CAULK 社 IRM

*12）共和理研 マニピュレーターK116M 


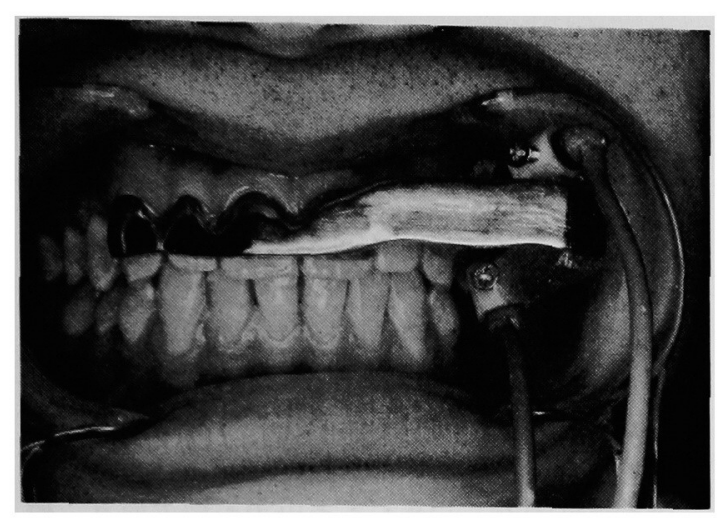

图 8 口腔内に固定された変位測定装置

2）口空内への固定

口角鉤を用いて被験者の口唇, 頓粘膜を排除し た後, ターゲットの付いたレジンブロックを設定 用コアを用いて被験歯唇面にシアノアクリレート 接着材で貼付し, メタルシーネを固定源歯列に仮 着用セメント*12)で固定した。

ついで較正によってブリッジの平衡が得られた 状態のコイルセンサをハウジング内に装着し，ブ リッジの平衡がくずれないよらにセンサの位置を 調整した。ブリッジのバランスが $\pm 0 \mathrm{mV}$ となっ たところを原点とし，この状態から測定を開始し た（図 8)。

\section{5. 較 正}

ロ腔内に装置を固定する前に，較正のため口腔 外で以下の操作を行った。

(1) 変位量に対する較正のため較正器上で, 夕 ーゲットをX方向あるいはY方向にそれぞれ0か ら50 $\mathrm{m}$ まで往復移動させ, その出力をX-Yレ コーダに記録する。

（2）荷重量に対する較正のため荷重計，咬合力 計に各 $500 \mathrm{~g}, 2 \mathrm{~kg}$ の荷重量を加光, その出力を $\mathrm{X}-\mathrm{Y} レ$ ーダに記録する。

以上の操作を各 10 回反復し，記録された值の平 均值をそれぞれ CAL (X), CAL (Y), CAL (500 g ), CAL (2kg), として較正に供した。

\section{6. 実験方法}

\section{1) 米の変位測定}

被験者を歯科用治療椅子に座らせ，頭部を安頭 台で支え床面に対して約 120 度の後傾位をとら せ，以下の条件下での犬米の変位測定を行った。

(1) 側方滑走運動時

下顎安静位から咬頭嵌合位へ閉口した後，任意 の速度扣よび力で犬歯の咬頭対咬頭位まで側方滑 走運動し開口する動作を，約 5 秒間隔で10回ずつ 行わせた。

（2）荷重時

荷重用アダプタを仮着用セメントで固定し，荷 重時の歯の変位測定を行った。

i ）手指荷重

500～700 g の荷重を 1〜2秒間加えた後, ただ ちに除重する。

ii) 咬合荷重

咬合力計からの出力をデータレコーダ上でモ二 ターしつつ, 2〜3kgの荷重が加わるように咬合 力計の咬无しめを $1 \sim 2$ 秒間行わせた。

なお，双方の荷重とも10回ずつ行ったが，それ ぞれ除重後 X-Yレコーダのペンが元の位置に復 㷌するのを待ってからつぎの荷重を行らようにし た。

2）下顎運動路の記録

歯の変位測定装置を口腔内より除去した後, サホン・ビジトレーナーを用いて切霜点前方 10 $\mathrm{mm}$ に設けた測定点についてつぎの下顎運動を前 頭面で記録した。

（1）空口時の開閉および左右側方滑走運動

(2) チューインガム*13)咀嚼運動

習慣性咀嚼側でチューインガム咀嚼を 3 回行わ せたが，各回の咀嚼についてチューインガムが十 分に軟化した時の 15 ～20ストロークをブラウン 管上でモニターしつつデータレコーダ*14) に収録 した。

\section{7. 測定期間}

測定は舌面装置装着前, 装着中, 除去後の 5 週 間にわたり12〜16回行った。

*13） ワーナー・ランパート K. K. A. トライデント

*14）東京歯材社 サホンデジタルレコーダー model CMT-2 
表 4 は各実験日扣よびその日に行った奏験内容 を被験者ごとに示したもので，○は犬歯の変位測 定, ○は切齿点の下顎運動路の記録である。なお， 舌面装置装着直前 (BS) と装置装着直後 (SET), および装置装着 21 日後（S-21）上装置除去直後 (REM) はそれぞれ同一日である。実験を行った 時刻は各被験者間では異なるが，同一被験者では 各実験日ともほぼ同じである。

\section{8. 測定項目}

データレコーダに収録された雨の変位について のデータはX-Yレコーダに，下顎運動路のデー タはX-Yプロッタ*15)に表示した。

(1) 歯の変位
米の变位に関しては, 頖舌方向をX軸, 歯冠軸 方向をY軸として 2 次元表示した。一方，荷重と 変位の関係については荷重計および咬合力計から の出力を $\mathrm{X}$ 軸, 頓舌方向センサからの出力を $\mathrm{Y}$ 軸 として表すことにした。

側方滑走運動時あるいは荷重時に生じる犬雪の 变位は煩側, 歯根方向へ直線的であることから （四9）この変位経路をべクトル化し，その距離 を変位量, 煩舌方向の基準線に対する角を変位方 向とした。X-Y レコーダ上に描記された煩舌お。 よび歯冠軸方向センサからの出力を読み取り，較 正時に求めた $\mathrm{CAL}(\mathrm{X}), \mathrm{CAL}(\mathrm{Y})$ を用いて各方 向の移動距離に換算し（図10，式- a， b )，これ

表 4 測定期間，実験日および実験内容

\begin{tabular}{|c|c|c|c|c|c|c|c|c|}
\hline \multirow{2}{*}{$\begin{array}{l}\text { 回 } \\
\text { 数 }\end{array}$} & & \multirow{2}{*}{ 実 験 日 } & \multicolumn{6}{|c|}{ 被験者および実験内容. } \\
\hline & & & A & B & C & D & E & F \\
\hline 1 & \multirow{4}{*}{$\begin{array}{l}\text { 装 } \\
\text { 着 } \\
\text { 前 }\end{array}$} & 装着 7 日前（BS -7） & 0 & 00 & 00 & 00 & 100 & 00 \\
\hline 2 & & 装着 3 日前（BS -3） & 0 & 0 & 0 & & & \\
\hline 3 & & 装着 1 日前（BS-1） & 0 & 0 & 0 & 00 & 00 & 00 \\
\hline 4 & & 装着直前（B S） & 0 & 0 & 0 & & & \\
\hline 5 & \multirow{4}{*}{ 装 } & 装着直後 (SET) & 0 & 00 & 0 & 00 & 00 & 00 \\
\hline 6 & & 装着 1 日後 $(S-1)$ & 00 & 00 & 00 & & & 00 \\
\hline 7 & & 装着 3 日後 ( $S-3)$ & O & 00 & 0 & 0 & 00 & 00 \\
\hline 8 & & 装着 7 日後（S-7） & 00 & 00 & 00 & 00 & 00 & 00 \\
\hline 9 & 着 & 装着10日後（S-10） & 0 & 0 & 0 & 00 & 00 & 0 \\
\hline 10 & \multirow[t]{3}{*}{ 中 } & 装着14日後（S-14） & 0 & 00 & 00 & 00 & 00 & 00 \\
\hline 11 & & 装着17日後（S-17） & 0 & 0 & 0 & 0 & 00 & 00 \\
\hline 12 & & 装着21日後（S-21） & 00 & 00 & 00 & 00 & 0 & 100 \\
\hline 13 & \multirow{4}{*}{$\begin{array}{l}\text { 除 } \\
\text { 去 } \\
\text { 後 }\end{array}$} & 除去直後（REM） & 0 & 0 & 0 & & & \\
\hline 14 & & 除去1日後 (R-1) & 0 & 0 & 0 & & & \\
\hline 15 & & 除去 3 日後 (R-3) & 0 & 0 & 0 & 00 & 00 & 00 \\
\hline 16 & & 除去 7 日後 (R-7) & 0 & 100 & 00 & 100 & 00 & 00 \\
\hline
\end{tabular}

*15)渡辺測器 サーボプロット DA 8400 

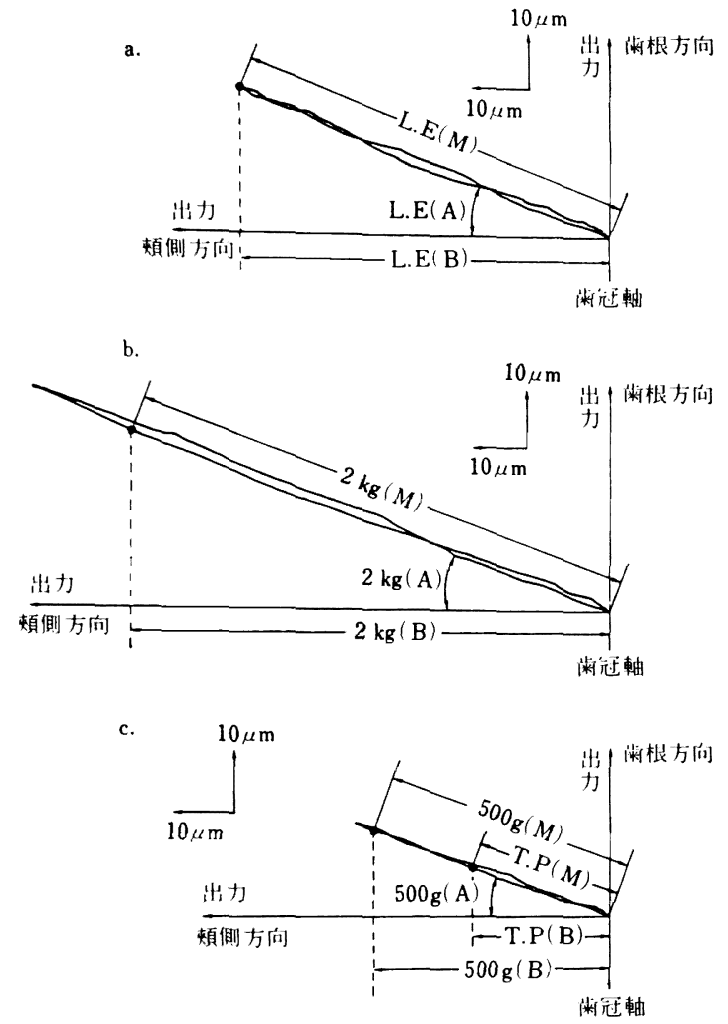

図 9 犬蔽の变位様相

a : 側方滑走運動時 (L. E)

b ：咬合荷重時

c : 手指荷重時

M， A， B はそれでれ変位量，変位方向，煩側方向 移動距離を示し, T. P は変曲点を表す

より変位量および変位方向を算出した(図10, 式一 c, d )。

なお, 荷重時の雬の変位量および変位方向につ いては $500 \mathrm{~g}, 2 \mathrm{~kg}$ 荷重時, および 荷重一変位曲 線から得られる変曲点に対応する荷重時を対象と した。すなわち，荷重計あるいは咬合力計からの 出力と煩舌方向センサからの出力とで描かれる荷 重一変位曲線より較正時に求めた CAL（500 g ） と CAL (2 kg) に対応する頓側方向の変位出力 (500 g (B), $2 \mathrm{~kg}$ (B)) を読み取り（図10)，これを 各変位経路上にあてはめて経路上での点を求め, それぞれの場合の变位量を算出し，さらにこの点
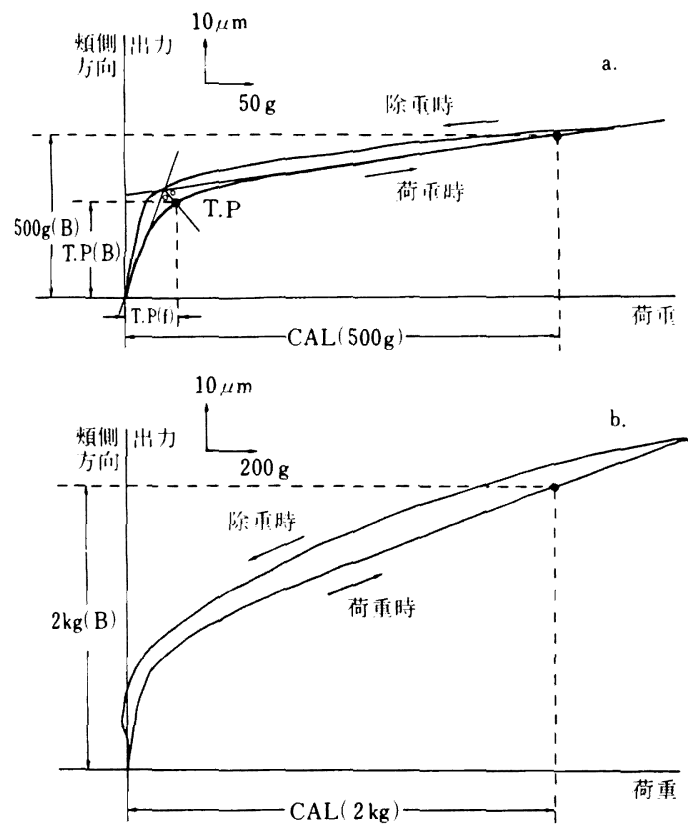

図10 荷重一変位曲線

$$
a \text { ：手指荷重時 b : 咬合荷重時 }
$$

<計算式 $>$

式- $\mathrm{a}$ ：煩側方向移動距離=煩舌方向センサからの 出力 $/ \mathrm{CAL}(\mathrm{X}) \times 50(\mu \mathrm{m})$

式一 $\mathrm{b}$ : 蔌根方向移動距離=蔽冠軸方向センサから の出力 $/ \mathrm{CAL}(\mathrm{Y}) \times 50(\mu \mathrm{m})$

式 $-\mathrm{c}$ : 変位量 $=$

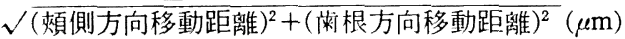
式 $-\mathrm{d}:$ 变位方向 $=$

$\tan ^{-1}$ (歯根方向移動距離/煩側方向移動距離)（度） 式- e : 变曲点における荷重量 $(\mathrm{T} . \mathrm{P}(\mathrm{F}))=$

T.P (f) $/$ CAL $(500 \mathrm{~g}) \times 500(\mathrm{~g})$

と原点を結ぶ線の方向を算出して変位方向とした (図 $9-b, c$ )。

一方, 荷重一変位曲線は 2 相性を呈するので初 期相および第 2 相の曲線に対する各接線の交わる 角の 2 等分線と荷重一変位曲線との交点を変曲点 (T.P）とし, 手指荷重時についてのみこの点に 相当する煩側方向の変位出力 (T. P (B)) および 
荷重出力 (T. P (f) ) を読及取り（図10-a)，とれ よりこの点に拈ける歯の変位量 (T.P $(\mathrm{M})$ ) (図 $9-\mathrm{c}$ ), 荷重量 (T.P $(\mathrm{F})$ )（図10, 式一 e ) 算出 した。

上記の方法により以下の 8 項目について各 10 回 の平均値を求めた。

i 側方滑走運動時の変位量 (L. E $(\mathrm{M})$ )

ii $500 \mathrm{~g}$ 荷重時の变位量 $(500 \mathrm{~g}(\mathrm{M}))$

iii $2 \mathrm{~kg}$ 荷重時の変位量 $(2 \mathrm{~kg}(\mathrm{M}))$

iv 変曲点に扣ける変位量 (T. P (M) )

$\mathrm{V}$ 側方滑走運動時の変位方向 (L. E (A))

vi $500 \mathrm{~g}$ 荷重時の变位方向 $(500 \mathrm{~g}(\mathrm{~A}))$

vii $2 \mathrm{~kg}$ 荷重時の変位方向 $(2 \mathrm{~kg}(\mathrm{~A}))$

viii 変曲点に打梳荷重量 $(\mathrm{T} . \mathrm{P}(\mathrm{F}))$

(2) 下顎運動路

舌面装置を装着することにより側方滑走運動の 前頭面投影経路の傾斜は急になる。これは図11に 示すごとく, 咬頭嵌合位により $3 \mathrm{~mm}$ 側方の滑 走運動路上の点と咬頭嵌合位とを結んだ線が正中 線となす角で表した（図11-a）。

チューインガム咀嚼運動路については咬頭嵌 合位より $1 \mathrm{~mm}$ 下方位, $3 \mathrm{~mm}$ 下方位の左右幅径 （図11-b，c）を30ストロークについて测定し， その平均值を求めた。

なお，角度の测定には分度器を，また長さの測 定には $1 / 100 \mathrm{~mm}$ まで読み取れるデジタルノギ ス*16)を用いた。

\section{III. 研 究結果}

\section{1. 犬歯の変位}

Group-functioned 咬合を有する被験者 F は他 の犬歯誘導咬合を有寸る被験者 $\mathrm{A} \sim \mathrm{E}$ と条件が異 なるので別に記しだ。

1）変位量の変化（被験者 $\mathrm{A} \sim \mathrm{E}$ ）

図12，13は被験者Aにおける被験歯，対照歯の 各変位量およびそれの煩側, 歯根方向の移動距離 についての経時的変化を示したものである。舌面 装置装着の影響を調べるため装置装着後の変位量 を装着前のものと比較することにし, 装置装着前

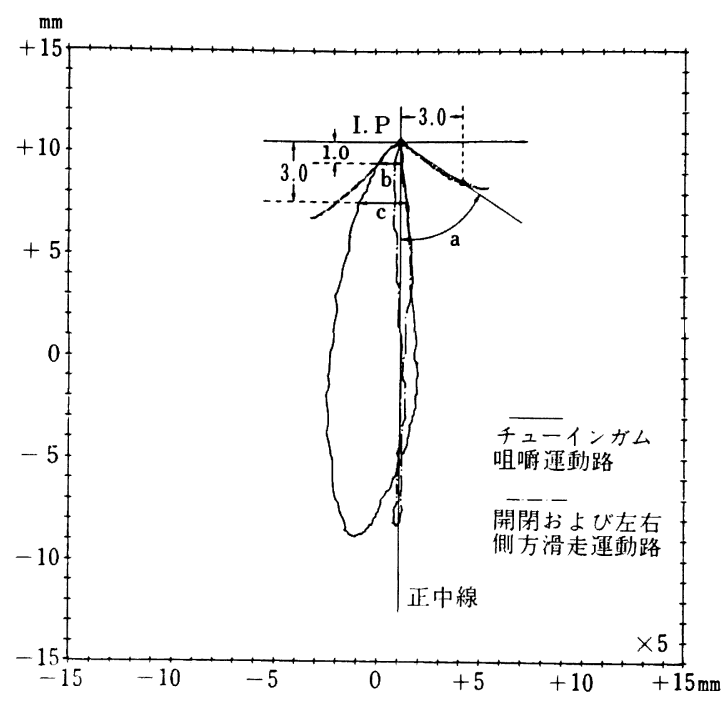

図11 下顎運動路の記録（前頭面） a : 側方滑走運動時の傾斜角

b : $1 \mathrm{~mm}$ 下方位の左右幅径

c : $3 \mathrm{~mm}$ 下方位の左右幅径

の実験日, BS-7, BS-3, BS-1, BS の变位量の平 均值を基準值として（図12, $\mathrm{a} \sim \mathrm{h}$ )，装置装着後 の変位量を基準值からの差で表した。

表 5〜8は各被験者の被験歯, 対照歯の基準值, 図14，15はそれぞれの舌面装置装着から除去後に 至るまでの変位量の基準値からの差の変動を示し たものである。

(1) 側方滑走運動時の变位量 (L.E $(\mathrm{M})$ )

被験者 $\mathrm{A} \sim \mathrm{E}$ の被験歯および対照雨の側方滑走 運動時の変位量 (L. E (M)) の基準 值は 35〜75 $\mu \mathrm{m}$, 平均 $54.7 \mu \mathrm{m}$ であった（表 5 ）。被験歯と対 照歯の基準值を被験者ごとに比較すると被験者 C で両者間に有意差がみられた。

図14からは, 被験歯の変位量は対照歯に比べ舌 面装置装着後徐々に増加した後減少し, 装着21日 後（S-21）には，基準值にほとんど戻ることがう かがえる。そして装置除去後は大きな変化がみら れない。変位量の増加が頂点に達する時期は被験 者 $\mathrm{A}, \mathrm{C}$ で装置装着 7 日後 $(\mathrm{S}-7)$, 被験者 $\mathrm{B}$, $\mathrm{D}$ で装置装着 10 日後（S-10）, 被験者 $\mathrm{E} て ゙$ 装置装 

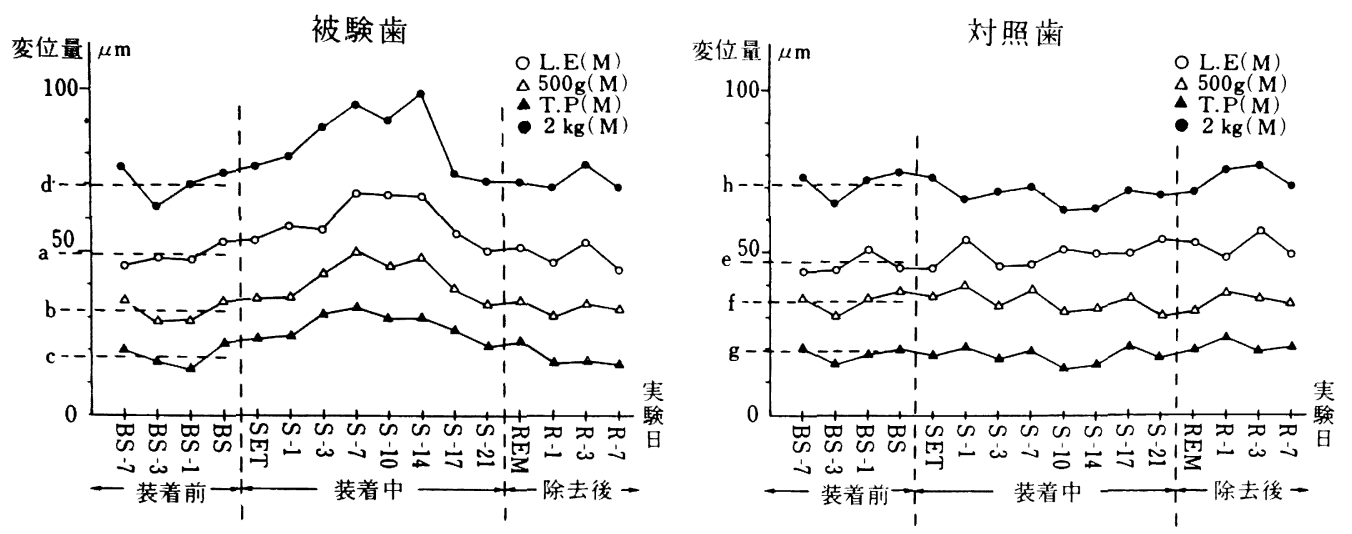

図12 各変位量の経時的变化（被験者 $\mathrm{A}$ )

$\mathrm{a}$ ：被験㐘の L. E (M) の基準値

$\mathrm{b}$ : 被験菌の $500 \mathrm{~g}(\mathrm{M})$ の基準值

$\mathrm{e}$ ：対照㐘の L. E (M) の基準值

c : 被験菌の T. P (M) の基準值

$\mathrm{f}$ ：対照蔽の $500 \mathrm{~g}$ (M) の基準值

$\mathrm{d}$ : 被験蒌の $2 \mathrm{~kg}$ (M) の基準值

$\mathrm{g}$ ：対照㐘の T.P (M) の基準值

$\mathrm{h}$ : 対照菊の $2 \mathrm{~kg}(\mathrm{M})$ の基準值

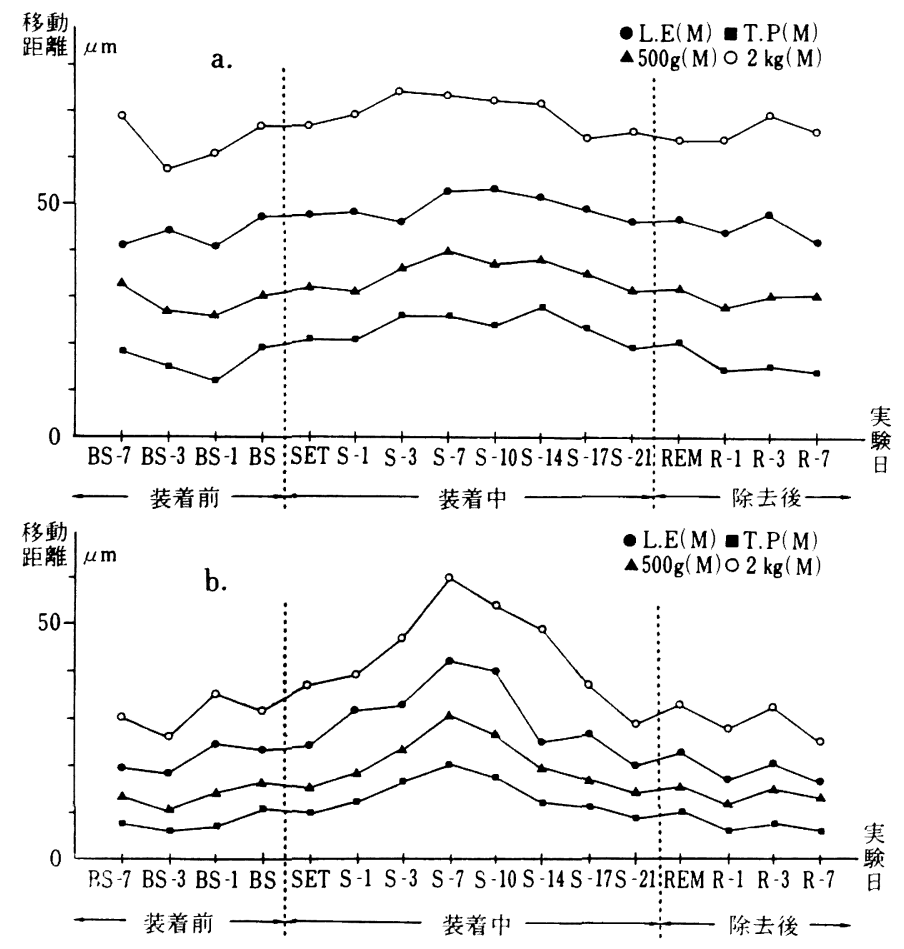

网13 変位量を各方向の移動距離に分けた時の経時的变化（被験者 $\mathrm{A}$ 一被験蔽）

$\mathrm{a}$ ：煩側方向移動距離

$\mathrm{b}$ : 瞥根方向移動距離 
着14日後（S-14）であった。また頂点に達した 時の基準值に対する増加量は 15〜32 $\mu \mathrm{m}$ であっ た。

（2） $500 \mathrm{~g}$ 荷重時の変位量 $(500 \mathrm{~g}(\mathrm{M}))$

各被験者の $500 \mathrm{~g}$ 荷重時の基準值は 22 57 $\mu \mathrm{m}$, 平均 $37.9 \mu \mathrm{m}$ で（表 6 ), 被験者 B，Cでは被験 雨と対照雨との間に有意差が認められた。

図15は，被験者 $\mathrm{E}$ を除き被験歯の变位量は対照 歯と比較して舌面装置装着後緩やかに増加した後 減少することを示している。変位量の増加が頂点 に達する時期は装置装着 $7 \sim 14$ 日後（S-7〜14） で，その時の基準値に対する増加量は 17〜24 $\mu \mathrm{m}$ であった。また装着21日後（S-21）にはい寸゙れ も基準値に近い值を示し, 除去後も安定した值を
示した。

(3) 変曲点における変位量 (T. P (M) )

変曲点に拈ける変位量の基準值は $10 \sim 26 \mu \mathrm{m}$, 平均 $19.9 \mu \mathrm{m}$ で, 被験者 B, Cでは被験霜と対照 歯との間に有意差がみられた（表 7 ）。被験崡の 変位量は $500 \mathrm{~g}$ 荷重時と同様の増減傾向を示した が，変位量の最大増加量は基準值に対し，16〜21 $\mu \mathrm{m}$ であった。

(4) $2 \mathrm{~kg}$ 荷重時の変位量 $(2 \mathrm{~kg}(\mathrm{M}))$

$2 \mathrm{~kg}$ 荷重時の変位量の基準値は $65 \sim 89 \mu \mathrm{m}$, 平均 $77.8 \mu \mathrm{m}$ で, 被験者 $\mathrm{B}, \mathrm{C}$ では被験歯と対照 歯との間に有意差がみられた（表 8 ）。

被験歯の変位量の変化傾向は他の場合とほぼ同 様であるが，変位量の増加が頂点に達する時期は
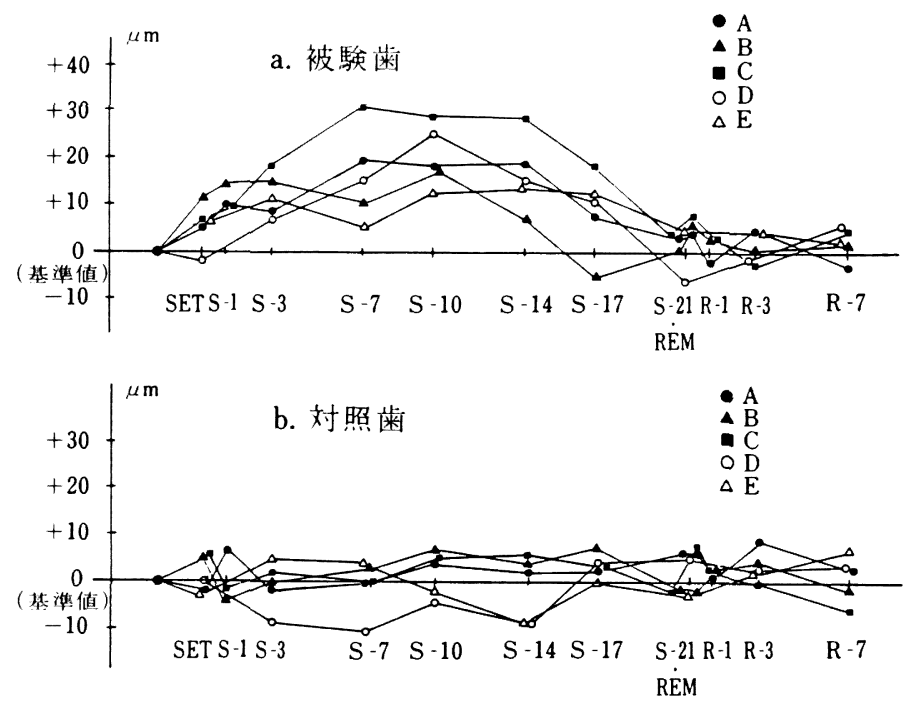

闵14 側方滑走運動時の変位量 (L.E $(\mathrm{M})$ ) の基準值との差の経時的変化 A， B， C， D， E：それぞれ被験者を表す

表 5 側方滑走運動時の变位量 (L.E (M)) の基準值

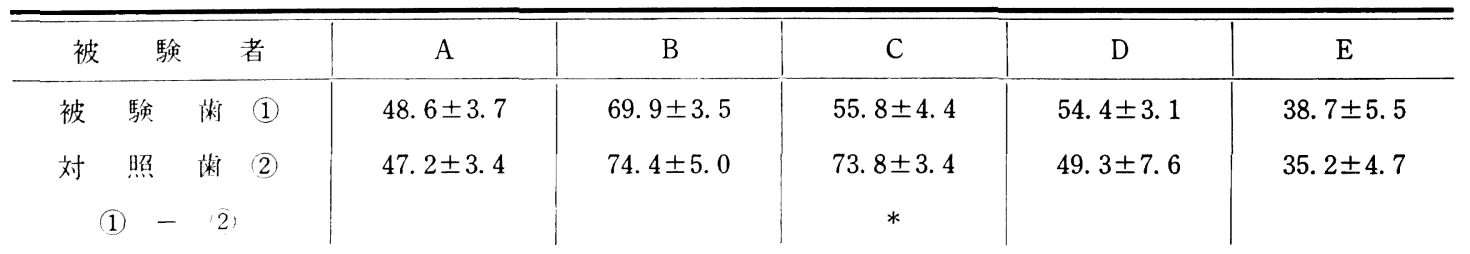

*有意水準 $1 \%$

単位 $(\mu \mathrm{m})$ 


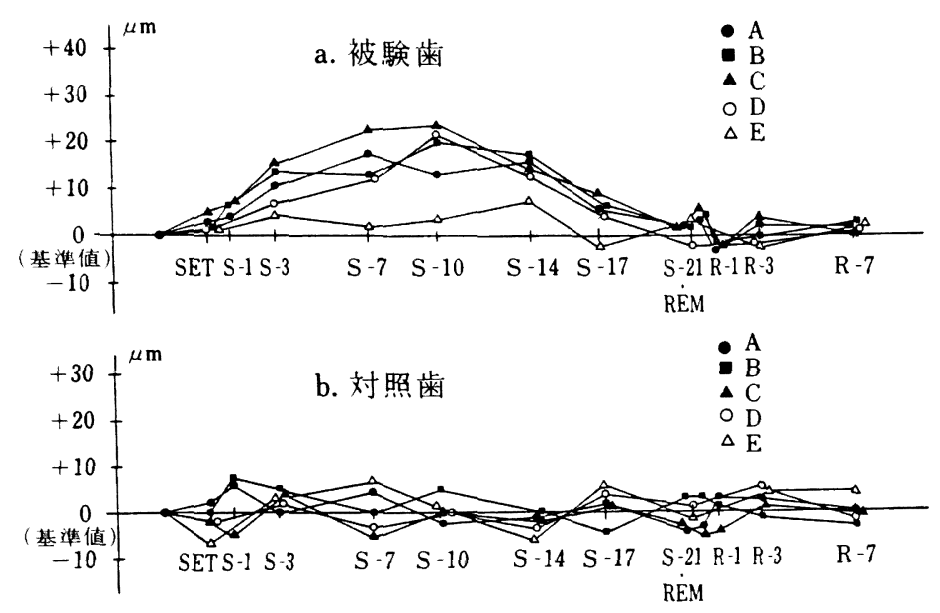

困15 $500 \mathrm{~g}$ 荷重時の変位量 $(500 \mathrm{~g}(\mathrm{M}))$ の基準值との差の経時的変化 A， B， C，D，E：それぞれ被験者を表す

表 $6500 \mathrm{~g}$ 荷重時の変位量 $(500 \mathrm{~g} \quad(\mathrm{M}))$ の基準值

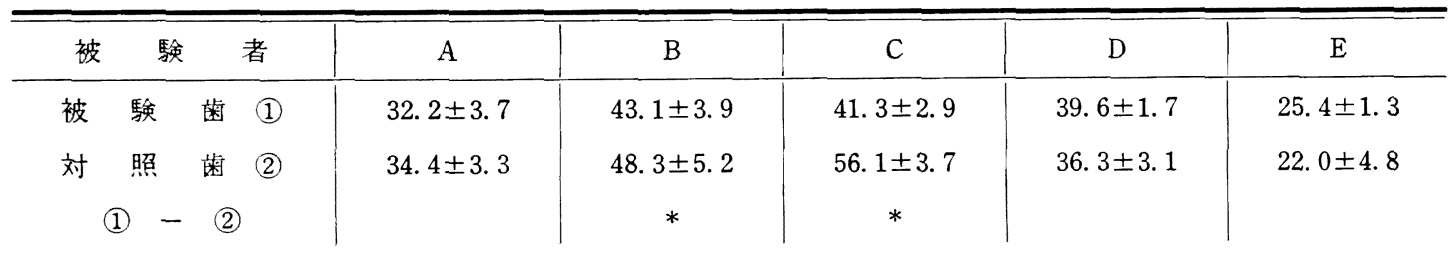

*有意水準 $1 \%$

装置装着10１4日後（S-10〜14）であり，その 時の基準値に対する最大増加量は 15〜30 $\mu \mathrm{m}$ で あった。

（5）被験歯と対照齿の変位量

被験歯と対照歯の变位量を比較するため, 装置 装着および除去後の各実験日における L. E (M)， $500 \mathrm{~g}(\mathrm{M}), \mathrm{T} . \mathrm{P}(\mathrm{M}), 2 \mathrm{~kg}$ (M) の值の基準值と の差を被験歯および対照歯についてそれぞれ求 め，その平均値を被験歯と対照歯との間で各実験 日ごとに検定した（表 9 ）。

被験者 5 例中 4 例で舌面装置装着後 $1 \sim 2$ 週後 の間で被験歯の変位量は対照歯と比較して著明な 増加を示した。しかし，装置装着 3 週後扣よび装 置除去後は被験歯と対照歯の間に差はなくなっ た。

(6) 各变位量の間の関係

変曲点における変位量 (T.P (M)) に対して,
側方滑走運動時の変位量 (L.E $(\mathrm{M}))$ および $2 \mathrm{~kg}$ 荷重時の変位量 $(2 \mathrm{~kg}(\mathrm{M}))$ との相関性を検討し た（表10）。その結果，被験歯の変位量の変化が 認められなかった被験者 $\mathrm{E} を$ 除く他の例では高い 相関性が認められた。

2）変位方向の変化（L. E (A), $500 \mathrm{~g}$ (A), 2 $\mathrm{kg}(\mathrm{A})) （$ 被験者 $\mathrm{A} \sim \mathrm{E}$ )

図16は被験者 $\mathrm{A}$ の被験歯の各变位方向の経時的 変化を示したものである。同一実験日での L. E (A), $500 \mathrm{~g}$ (A), $2 \mathrm{~kg}$ (A) の值は大差ない。これ は他の被験者 $\mathrm{B} \sim \mathrm{E}$ の被験歯, 対照歯についても 同様で同一実験日での L. E (A), $500 \mathrm{~g}$ (A), $2 \mathrm{~kg}$ (A) の值の差は 5 度以下であった。そこで，この 3 者の值の平均値をその実験日の变位方向の值と して, 変位量の場合と同様に, 舌面装置装着前の 実験日，B S-7, B S - 3, B S - 1, B S に求 めた変位方向の値の平均値を基準值として, 装置 
表7 変曲点における変位量 (T.P (M)) の基準值

\begin{tabular}{|c|c|c|c|c|c|c|c|}
\hline 被 & 験 & 者 & A & B & $\mathrm{C}$ & $\mathrm{D}$ & $\mathrm{E}$ \\
\hline 被 & 験 & 篓 (1) & $18.1 \pm 3.6$ & $19.4 \pm 3.3$ & $24.3 \pm 3.1$ & $17.5 \pm 1.9$ & 13. $0 \pm 3.4$ \\
\hline 対 & 照 & $\begin{array}{l}\text { 蹸 (2) } \\
\text { (2) }\end{array}$ & $19.1 \pm 2.3$ & $\begin{array}{c}24.5 \pm 3.1 \\
*\end{array}$ & $\begin{array}{c}36.1 \pm 3.5 \\
*\end{array}$ & 16. $4 \pm 2.3$ & $10.8 \pm 3.6$ \\
\hline
\end{tabular}

*有意水準 $1 \%$

単位 $(\mu \mathrm{m})$

表 $82 \mathrm{~kg}$ 荷重時の変位量 $(2 \mathrm{~kg}(\mathrm{M}))$ の基準值

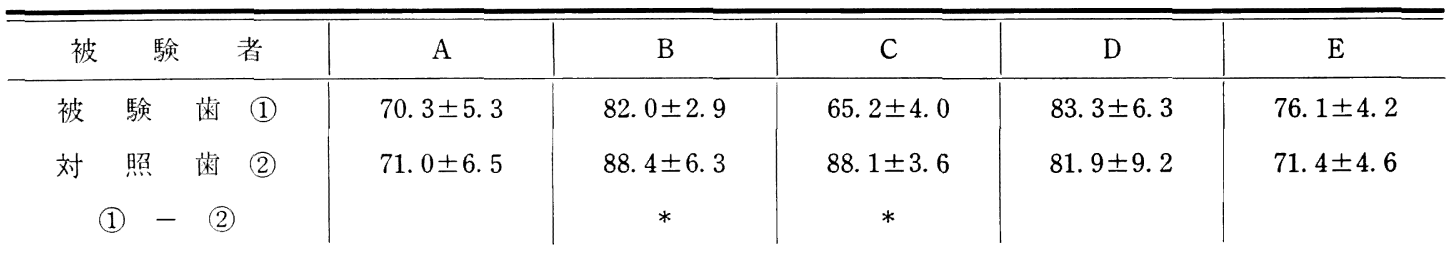

*有意水準 $1 \%$

単位 $(\mu \mathrm{m})$

表 9 被験苇と対照歯の変位量の变化の比較 ( $\mathrm{t}$-Test)

\begin{tabular}{l|llllllllll}
\hline & 奉験目 \\
\hline
\end{tabular}

装着後の変位方向の值と比較することにした（表 11, 図17)。

被験歯および対照歯の変位方向の基準值は21〜 47 度, 平均 32.2 度で, 被験歯と対照歯について比 較すると, 被験者 Bを除いて両者の間に有意差が みられた (表11)。

図17は舌面装置装着中および除去後の変位方向 の值を基準值との差として表したものの経時的変 化である。舌面装置装着期間中の变化を被験歯と
対照歯でみると, 被験者 $\mathrm{D}, \mathrm{E}$ では, 双方とも安 定した値を示した。他の被験者では，前項の変位 量の変化の場合と同様緩やかに増加した後減少す る変化がみられた。

変位方向の值の増加が頂点に達する時期は装置 装着 7 ～14日後（S-7〜14）で，その時の基準 值に対する増加量は 7 ～10度であった。

3）変曲点に拈ける荷重量の变化（T. P (F)） (被験者 $\mathrm{A} \sim \mathrm{E}$ ) 
表10 L.E (M) および $2 \mathrm{~kg}(\mathrm{M})$ と T.P (M) との相関係数

\begin{tabular}{|c|c|c|c|c|c|c|c|}
\hline \multirow{2}{*}{ 被 験 者 } & \multirow[b]{2}{*}{ A } & \multirow[b]{2}{*}{ B } & \multirow[b]{2}{*}{$\mathrm{C}$} & \multirow[b]{2}{*}{ D } & \multirow{2}{*}{$\mathrm{E}$} & \multicolumn{2}{|c|}{$\mathrm{F}$} \\
\hline & & & & & & 咀 嚼 側 & 非咀嚼側 \\
\hline L. E (M) & 0.891 & 0.906 & 0.903 & 0.912 & 0.695 & 0.881 & 0.936 \\
\hline $2 \mathrm{~kg} \quad(\mathrm{M})$ & 0.896 & 0.841 & 0.950 & 0.911 & 0.764 & 0.893 & 0.956 \\
\hline
\end{tabular}

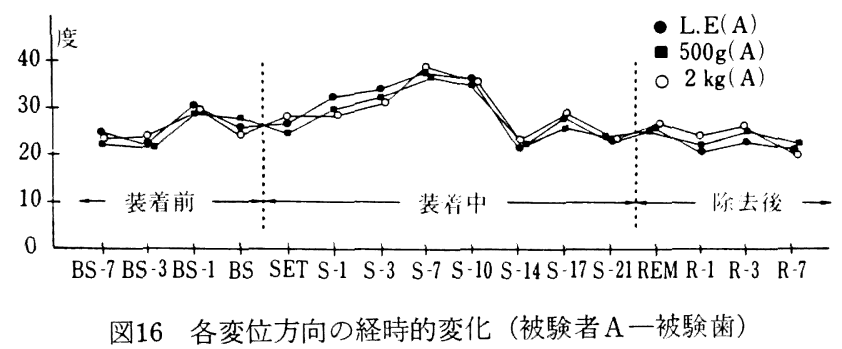

荷重一变位曲線の初期相と第 2 相との境を 変曲点としたが，被験歯および対照歯の各実験日 での変曲点に打ける荷重量 (T. P (F) ) を求め, その違いを経時的に観察するため, 変位量, 変位 方向の場合と同様の方法で基準值を求め, 舌面装 置装着後の値と比較検討した（表12, 図18）。

T.P (F) の基準值は 51 70 g, 平均 $61.1 \mathrm{~g}$ で, 被験歯と対照霜との間に有意差はなかった (表12)。

図18から，被験霜の T.P (F) には対照歯同様 比較的安定した状態がみられ，基準值との差は一 11. 0 + $16.0 \mathrm{~g}$ の範囲内に収まっていた。

\section{4）被験者 F の左右上顎犬米の変位状況}

被験者 $\mathrm{F}$ では左右上顎犬歯に舌面装置を装着し て両歯を被験歯としたが, 習慣性咀嚼側は右側で あった。他の被験者の場合と同様に, 変位量, 変 位方向および変曲点における荷重量の基準值を求 め（表13，14）, それに対して舌面装置装着後に 得られた值を比較検討した（図19,20）。

各変位量 (L. E (M), $500 \mathrm{~g}(\mathrm{M})$, T. P(M), $2 \mathrm{~kg}$ (M)) の基準値は左右上顎犬歯とも他の被験者と ほぼ同様の值を示し, 左右側の差は有意でなかっ た（表13）。

図19は舌面装置装着中および除去後の各変位量
の基準値との差の経時的変化である。左右犬歯と も变位量の增減傾向は他の被験者 $\mathrm{A} \sim \mathrm{D}$ の被験歯 の場合と同様で, 変位量の增加が頂点に達する時 期は右側 (咀嚼側) が装置装着 3 日後 $(\mathrm{S}-3)$, 左側 (非咀嚼側) が装着 14 日後（S-14）であっ た。またその時期の変位量の基準值に対する最大 増加量は右側犬霜が $14 \sim 20 \mu \mathrm{m}$, 左側犬歯が 10 $18 \mu \mathrm{m}$ であった。

各変位方向 (L. E (A), $500 \mathrm{~g}(\mathrm{~A}), 2 \mathrm{~kg}(\mathrm{~A}))$ の 基準值は右側犬歯が約 24 度，左側犬歯が約 29 度で 左右差がみられた（表14）。

図20-a は舌面装置装着中拈よび除去後の各変 位方向の值を基準值との差として表したものの経 時的変化であるが，同一実験日での各変位方向の 值には左右犬霜とも大差なく, 他の被験者 $\mathrm{A} \sim \mathrm{E}$ と同様であった。右側（咀嚼側）犬歯の変位方向 の值は舌面装置装着後緩やかに増加し, 装着 3 日 後（S-3）で頂点に達しその時の基準值に対す る増加量は11〜14度であった。その後徐々に減少 乙装着21日後（S-21）には基準值に戻り，除去 後も安定していた。一方, 左側 (非咀嚼側) 犬函 は装置装着中および除去後でわずかな増減傾向は あるものの比較的安定した值を示した。

変曲点に括ける荷重量（T.P (F)）の基準値は 


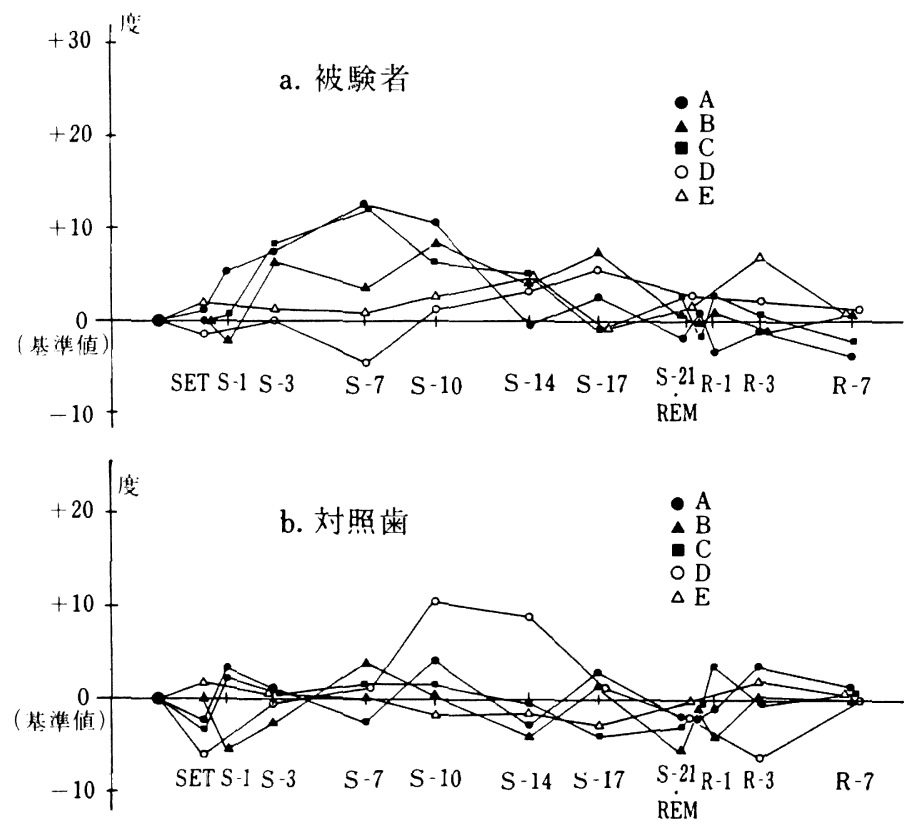

図17 变位方向の基準値との差の経時的変化

A， B， C，D，E：それぞれ被験者を表す

表11 変位方向の基準値

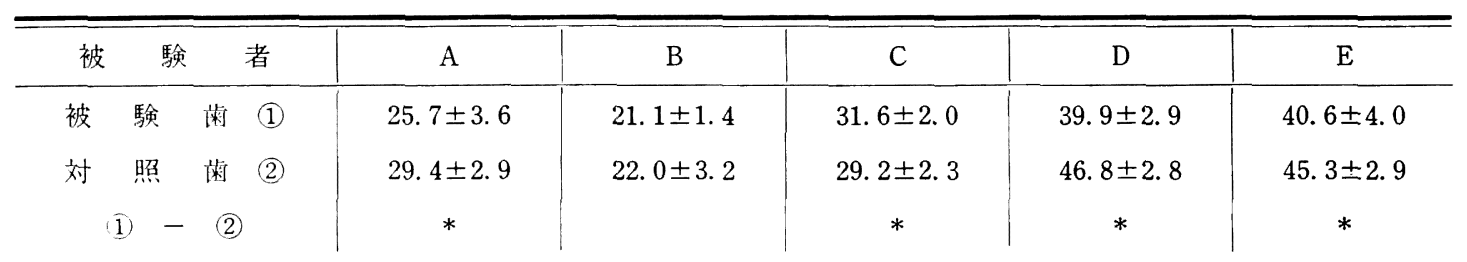

*有意水準 $1 \%$

単位(度)

左右犬歯とも他の被験者とほほ同様の值を示し, 左右差はみられなかった（表14）。

図20-b は舌面装置装着中拈よび除去後の T.P （F）を基準值との差として表したものの経時的変 化である。左右犬歯とも他の被験者同様大きな变 化はみられず，基準值との差はー6.7〜+9.5gの 範囲内であった。

\section{2. 下顎運動路}

1） 側方滑走運動路の変化

側方滑走運動路の前頭面投影傾斜角は舌面装置 装着により急になり, 装置装着中において傾斜角 の值に変化はみられなかった（図21）。
表15は舌面装置末装着時と装着時との傾斜角の 差を示したもので, $7.8 \sim 12.8$ 度, 平均 10.26 度, 標準偏差は1.95度となった。

2）チューインガム咀嚼運動路の変化

被験者 A， B， D， F では左右幅径は $1 \mathrm{~mm}$ 下方 位, $3 \mathrm{~mm}$ 下方位々も舌面装置装着後徐及に減少 し, 装置装着 7 １4日後で最小値を示した（図 $22)$ 。被験者 A, B , F の左右幅径は $1 \mathrm{~mm}$ 下方 位で約 $0.5 \mathrm{~mm}, 3 \mathrm{~mm}$ 下方位で約 $0.9 \mathrm{~mm}$ 減少 し, 被験者 $\mathrm{D}$ では $1 \mathrm{~mm}$ 下方位で $0.8 \mathrm{~mm}, 3 \mathrm{~mm}$ 下方位で $1.3 \mathrm{~mm}$ 減少して最小值に達した。その 後左右幅径は徐々に増加し, 装着21日後（S-21） 

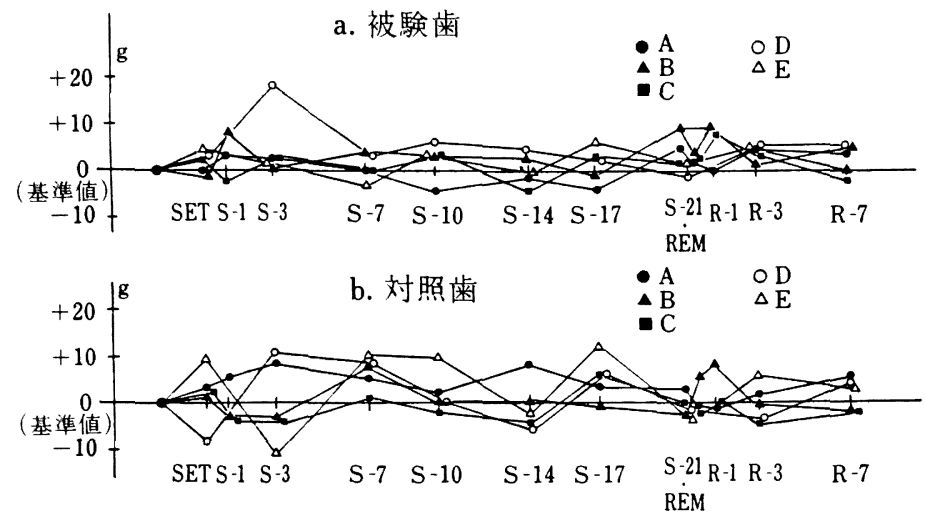

図18 变曲点における荷重量 (T. P (F)) の基準值との差の経時的变化

A， B， C， D， E：それぞれ被験者を表す

表12 変曲点における荷重量 (T.P (F)) の基準值

\begin{tabular}{ccc|c|c|c|r|r}
\hline \hline 被 & 験 & 者 & $\mathrm{A}$ & $\mathrm{B}$ & $\mathrm{C}$ & $\mathrm{D}$ & $\mathrm{E}$ \\
\hline 被 & 験 & 菌 & $60.7 \pm 3.7$ & $62.7 \pm 4.5$ & $70.0 \pm 6.4$ & $58.4 \pm 4.5$ & $51.9 \pm 6.4$ \\
対 & 照 & 桨 & $58.8 \pm 3.8$ & $65.3 \pm 5.4$ & $68.6 \pm 3.9$ & $59.0 \pm 10.6$ & $61.8 \pm 8.1$
\end{tabular}
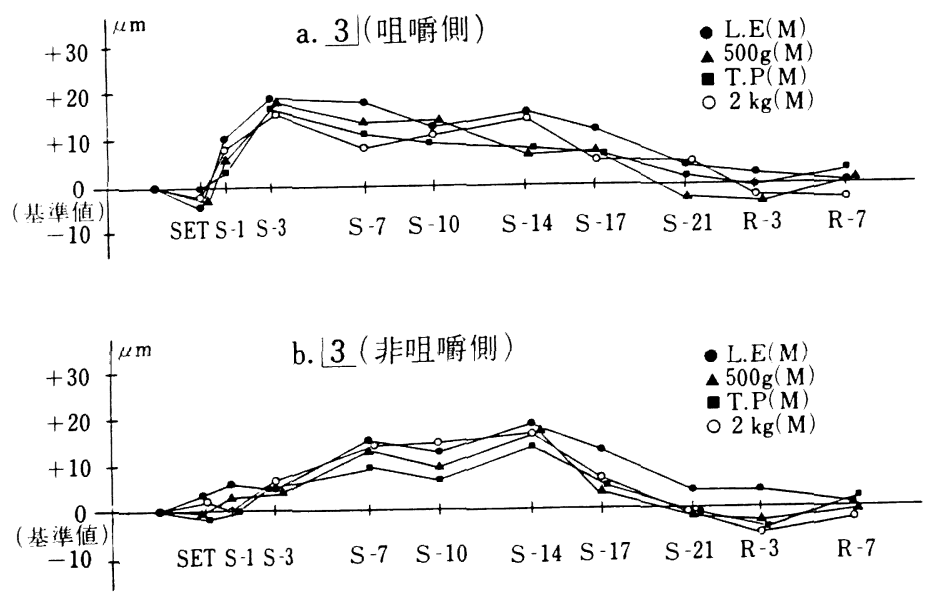

図19 各変位量の基準値との差の経時的変化（被験者 F）

表13 各变位量の基準值（被験者 $\mathrm{F}$ )

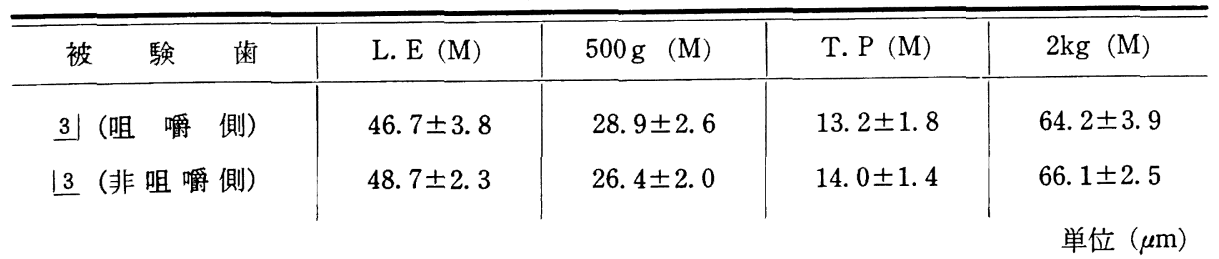



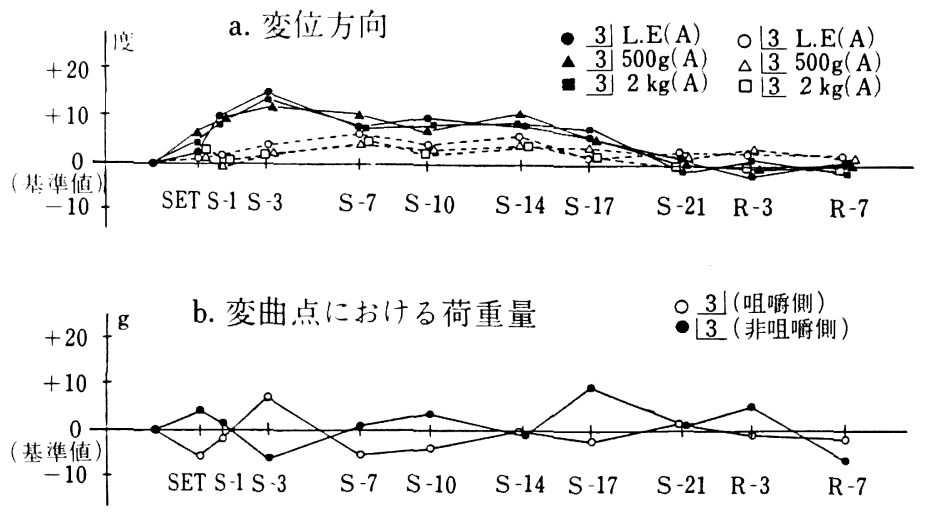

図20 各変位方向, 变曲点における荷重量の基準值との差の経時的変化（被 験者 F)

表14 各変位方向, 变曲点における荷重量の基準值

\begin{tabular}{|c|c|c|c|c|}
\hline 被験尚 & L. E (A) & $500 \mathrm{~g}(\mathrm{~A})$ & $2 \mathrm{~kg}(\mathrm{~A})$ & T. P (F) \\
\hline 니 (咀 嚼 側) (1) & 23. $7 \pm 1.0$ & $24.7 \pm 2.7$ & $24.7 \pm 2.3$ & $58.9 \pm 5.8$ \\
\hline 13 (非咀罦側) (2) & $29.3 \pm 1.3$ & $28.5 \pm 1.7$ & $30.8 \pm 1.0$ & $61.9 \pm 4.6$ \\
\hline (1) - (2) & $*$ & * & * & \\
\hline
\end{tabular}

*有意水準 $1 \%$

および除去後には装置装着前の值に戻り，全体と して凹型の变化傾向を示した。被験者 Cについて はほぼ同様の凹型の変化傾向を示したがあまり明 瞭ではない。被験者 $\mathrm{E} は$ は他と異なりほとんど変化 を示さなかった。

\section{IV. 総括および考察}

\section{1. 研究方法}

本研究は下顎運動を誘導する歯の誘導面を急に した場合に当該米および下顎運動にいかなる影響 が生ずるかを調べるため，上顎犬歯が誘導に関与 している被験者についてその犬雪の舌面傾斜を約 10度急にさせ, 歯の変位の変化, チューインガム 咀緭時の運動経路の変化を 5 週間にわたって経時 的に観察し検討したものである。

歯の変位測定については，従来より歯周組織の 機能状態を表す 1 つの指標として行われてきた が, Mühlemann ${ }^{8)}$, 石橋9) らの研究以来急速に進 歩し， 2 次元的10 13) さらには 3 次元的 ${ }^{14)}$ な測定
も試みられるようになってきた。

犬歯の変位測定に関しては, Curilović15) は12 名の被験者に overlay を装着し実験的犬歯誘導 咬合を作り10日間にわたってその変位量を観察 し, O'Leary ら ${ }^{16)}$ は group-functioned 咬合を有 する者と犬歯誘導咬合を有する者の上顎片側中切 歯から第 2 大臼歯までの各歯の変位量を測定して いる。また, Hofmann ${ }^{17)}$ は犬歯誘導咬合を有す る10名について荷重時㧍よび機能時の上顎犬歯の 変位量を測定している。

ここでは非接触微小変位センサを用いて煩舌, 歯冠軸方向の 2 方向から犬歯の変位測定を行っ た。測定は犬雪唇面のほぼ中央に固定されたレジ ンブロックの 2 面に貼付したターゲットについて 行って扣り，歯面あるいは歯冠軸上の点からはず れているため歯そのものの変位を表したものでは ない。しかし，舌面傾斜を変えたことにより生じ る変位の変化を経時的に観察し比較するにはさほ ど問題ではなく，むしろその再現性がより重要と 


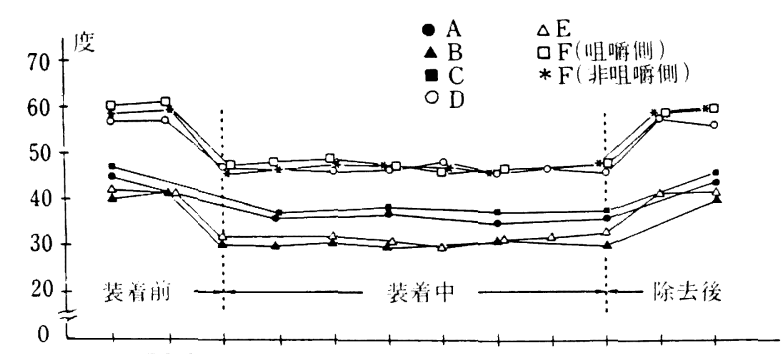

BS-7 BS-1 SET S-1 S-3 S-7 S-10 S-14 S-17 S-21 R-3 R-7

図21 側方滑走運動路前頭面投影傾斜角の経時的変化

A， B， C， D， E， F：それぞれ被験者を表す

表15 舌面装置装着による側方滑走運動路の前頭面投影傾斜角の差

\begin{tabular}{ll|c|c|c|c|c|c}
\hline \hline 被 & 験 者 & $\mathrm{A}$ & $\mathrm{B}$ & $\mathrm{C}$ & $\mathrm{D}$ & $\mathrm{E}$ & \multicolumn{2}{|c|}{$\mathrm{F}$} \\
\hline 角 度 & & & & & \\
差 & 8.8 & 7.8 & 10.4 & 10.7 & 8.7 & 12.6 & 12.8
\end{tabular}

単位（度）
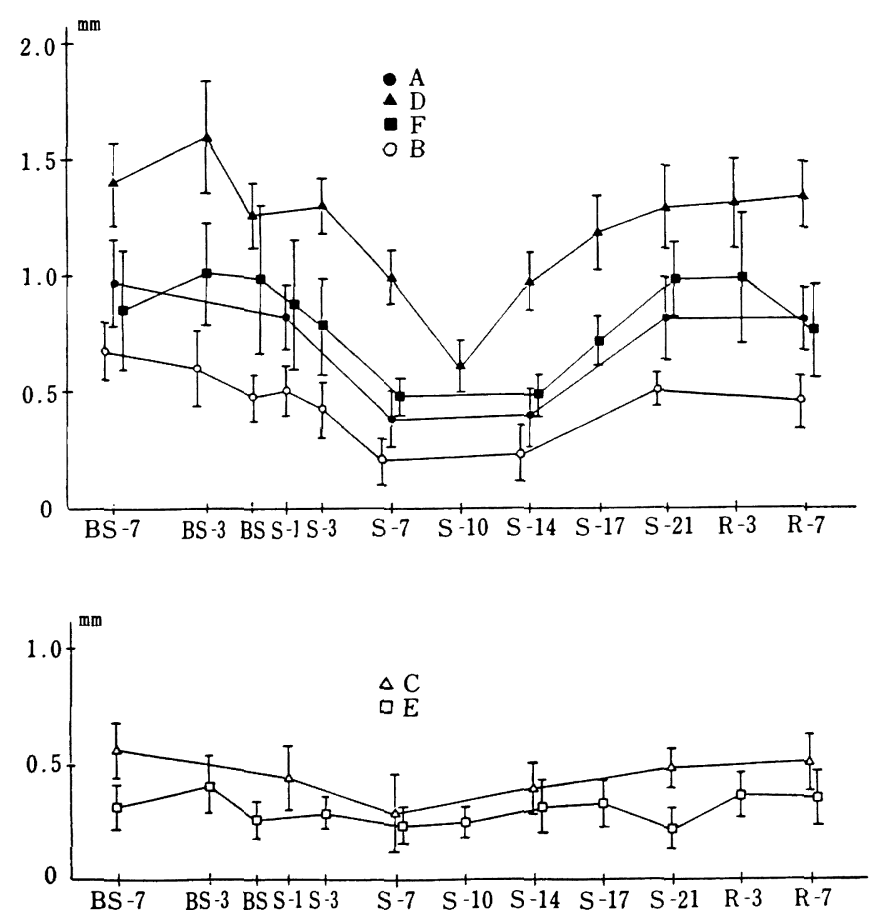

図22チューインガム咀嚼運動路の左右幅径の経時的変化 (1mm 下方位) A， B， C， D， E， F：それぞれ被験者を表す 
考觉てこの方法を採用した。

変位測定装置の設定に際しての犬雨・ターゲッ ト・コイルセンサの位置関係の再現性に関しては ターゲットブロック設定のためのコアの使用によ り可及的に同一条件が得られるように努めた。そ の結果は対照歯の変位量の安定性からみて（図 14,15-b）各被験者とも再現性は満足されている と考兄られた。

この他に実験の精度に影響を及ぼす要因として は唇側メタルシーネの動きや固定源とした上顎前 歯 4 歯の動きが挙げられる。とくに, 前歯が咬頭 嵌合位で接触する被験者では下顎運動時に固定が 不完全になる恐れがある。しかし奉際には, メタ ルシーネの緩みや咬頭嵌合位付近での前歯の強い 接触によると考兄られる犬歯の変位経路の乱れは 実験中において認められなかった。

\section{2. 研究結果}

1）歯の変位

(1) 変位量の変化

6 被験者の犬雨の変位量は側方滑走運動時 で $54 \pm 12.9 \mu \mathrm{m}, 500 \mathrm{~g}$ 荷重時で $36 \pm 10.1 \mu \mathrm{m}, 2 \mathrm{~kg}$ 荷 重時で $75 \pm 9.2 \mu \mathrm{m}(\mathrm{n}=12)$ の值を示し, 正常な 犬歯について 側方滑走運動時の变位測定をした Hofmann ${ }^{17)}$, 五十嵐 $5^{18)}, 500 \mathrm{~g}$ 荷重を加光た Curilovicic), O'Leary $5^{16)}$, 五十嵐 $5^{18)}, 2 \sim 3 \mathrm{~kg}$ の荷重を加えた Behrend19) の值とそれぞれ汪ぼ 一致する。

習慣性咀嚼側と非咀嚼側の上顎犬歯の変位量を 舌面装置装着前の状態で比較したところ, 被験者 B，Cでは有意差がみられ, 双方とも非咀緭側の 犬歯の方が 5 20 $\mu \mathrm{m}$ 大きい変位量を示した。こ の左右差については他の被験者では全歯が整って いるのに対し, 被騟者 Bでは非咀嚼側の下顎第 1 大曰歯が欠損しており, 被験者 Cでは非咀嚼側の 上顎臼歯部に橋義歯が装着されているため, 咀嚼 時の機能的要請が左右側で異なり, それが変位量 の差として表れたものと考えられる。

被験者 $\mathrm{E}$ を除く他の被験者では, 舌面装置を装 着すると被験歯の変位量は対照歯に比較して徐々 に増加し, 装置装着 $7 \sim 14$ 日後で頂点に達し, そ
の後徐々に減少して装着21日後および除去後には 大きな变化がなく装置装着前とほぼ同じ値を示し た。これについて, 被験歯と対照歯の変位量の差 として検討したところでは，4例において被験歯 の変位量の明らかな増加減少が認められ（表 9), 歯周組織の機能に一時的な变化が生じたことがわ

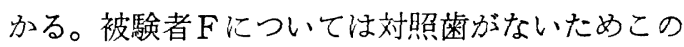
ような検討はできないが，被験苗の変化の傾向が 他の被験者の被験苗と同様であることからそれぞ れの歯周組織に同じような機能的变化が起こった ものと推測される。

歯の变位量は初期動摇の大きさによってほ注決 定されるといわれる20)。L. E (M), $2 \mathrm{~kg}(\mathrm{M})$ と T. P (M) との相関係数は, 被験者 $\mathrm{E}$ 以外では高 い值が得られて扣り（表10）, T. P (M) の変化が 他の二者の変化と密接に関係していることを示し ている。これは舌面装置装着後の被験歯の変位量 の変化が初期動摇量の変化, すなわち歯根膜の粘 弾性の変化に起因するものと考えられる。Curilovici $^{15)}$ は同様の実験を行い, 変位量の多少の変 動は認められたがそれは生理的範囲内であり大き な変化はなかったと報告している。Mühlemann ら 21$)$ は, 歯周組織が病的な状態であっても動摇 度は正常值を示すことがあり，正常な動摇度とい うのは加觉られた力が規格化されていても1つの 方法で表されるものではないと述べており，歯の 変位量のみで生理的と病的の境界を決めることは できないとしている。本研究で被験歯の変位量の 増加が認められた 5 例の $500 \mathrm{~g}(\mathrm{M})$ についてみる と， $500 \mathrm{~g}(\mathrm{M})$ の基準值に対する差は最大で+17

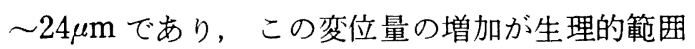
内に属するのかどらかは明らかではないが，臨床 上用いられる動摇度の診査を行ったところでは測 定期間中 6 例とも $\mathrm{M}_{0}$ であった。

Mühlemann $5^{22)}$, 石田 ${ }^{23)}$, 田中年は, イン レー,クラウンを用いて央験的咬合干渉を与えた 時に変位量の増加を認めているが， Mühlemann は, 増加した動摇量が減少し, 最終的には実験前の 状態掞よび対照歯の值より小さくなったことを述 べ, 骨の改造, コラーゲン線維の機能構造の改変 
の結果であると説明している。

今回，舌面傾斜を急にしたことにより変位量の 変化がみられたが, 舌面装置除去後の变位量の值 は装置装着前の值とほとんど変わらず，また被験 歯と対照歯との比較においても差がみられないこ とから霜周組織の機能構造には変化が起きていな いと考えてよいであろう。

(2) 変位方向の変化

側方滑走運動, 手指荷重, 咬合荷重の 3 種の異な る荷重を加え, 得られた変位方向の值 L. E (A), $500 \mathrm{~g}(\mathrm{~A}), 2 \mathrm{~kg}(\mathrm{~A})$ は同一実験日では 6 被験者之 も 5 度以内の小さなバラッキを示した。荷重方向 と変位経路について Körber ${ }^{25)}$, 斉藤 ${ }^{26)}$ は, 荷重 方向を変えても変位経路に差はないと報告してお り，本測定でも荷重方向に関しては正確な規制を 行ってないにもかかわらず，変位方向の值に大き な羑異はみられなかった。そこで同一実験日での L. E (A), $500 \mathrm{~g}$ (A), $2 \mathrm{~kg}$ (A)の平均值を変位方 向の值として経時的に観察したところ， 7 被験歯 中 4 例で変位方向の値は舌面装置装着期間中緩や かに増加後减少し, 装置除去後は安定していた。 荷重方向の差異は変位経路に影響を及ほささないと 考元るなら,この変位方向の值の変化は歯周組織 の機能状態の変化によるものかも知れない。

6 被験者とも犬歯は, 煩側, 歯根方向へ直線的 な変位経路を描いたが, Behrend ${ }^{19)}$ は犬歯の变位 について，犬歯舌面形態の傾斜が急な場合には， 犬歯の変位は歯根長の根尖側 $1 / 3$ 付近にある点を 中心とする回転だけではなく，根尖方向への歯体 移動をも含んだ移動により変位経路の傾斜も急に なると推測している。ここでの犬歯の変位を頓側 および歯根方向の移動距離に分けて観察すると, 舌面装置装着後の被験歯の変位方向の変化がみら れた被験者 A， B， C，Fでは，歯根方向の移動 距離は煩側方向に比べ増加後減少する変化傾向は より著明であった（図13）。これは舌面装置装着 により舌面の傾斜が急になり, 根尖方向への歯体 移動量が増加したことを意味しておりBehrendの 推測と一致している。

（3）変曲点における荷重量の変化
荷重一変位曲線についてはX軸は荷重量, Y軸 は頓舌方向センサからの出力あるいは菌冠軸方向 センサからの出力とする 2 種類の表示方法があ る。双方の荷重一変位曲線を描いて，それぞれか ら求めた変位量の值は注ぼ一致することを確認し ているが，歯冠軸方向センサからの出力を用いた ものでは荷重一変位曲線の 2 相性があまり明確で はない。よってここでは 2 相性が明確な煩舌方 向センサからの出力による荷重一変位曲線を用い た。

手指荷重, 咬合荷重の荷重方法の違いにより多 少異なった形の荷重一変位曲線が得られる（図 10)。各荷重一変位曲線から求めた $500 \mathrm{~g}(\mathrm{M}) の$ 值は注ぼ一致するが，変曲点を先に述べた方法で 求めると T. P (M), T. P (F) は異なる値となる。 手指荷重での荷重一変位曲線では荷重量 50 ～70 g の範囲に変曲点が存在するのに対し, 咬合荷重で は荷重量200３00 g の範囲になる。これは荷重に 用いた装置や加光た荷重量, 荷重方法などの差異 に起因すると考えられるが, 変曲点を求めるに当 たっては，歯の变位測定に際して従来より $500 \mathrm{~g}$ の荷重量が多く用いられていることから手指荷重 による荷重一変位曲線を用いて変曲点を求めるこ とにした。

歯に加兄られた力は歯根膜を介して歯槽骨に伝 達されるが, 荷重一変位曲線の初期相は歯根膜の 変形，第 2 相は歯槽骨の変形を表すとされてい る。本測定では初期相と第 2 相の境界を変曲点 （T．P）としたが，従来より健全な雨周組織では この点は $100 \mathrm{~g}$ 以下で現れるとされている。6 被 験者とも T.P (F) は50〜 70 g を示し, 舌面装置 装着中および除去後もこの值は大きく变化せず常 に $100 \mathrm{~g}$ 以下であった。これは舌面傾斜の変化に よる影響が歯槽骨にまで及んでおらず，歯根膜か ら歯槽骨への力の伝達は滑らかに行われているこ とを示咍するものである。

2）チューインガム咀嚼時の運動経路の変化

(1) 舌面装置の影響

チューインガム咀嚼時の下顎運動路を前頭面で 記録し, 各ストロークの開口路, 閉口路の左右幅 
径を咬頭嵌合位から $1 \mathrm{~mm}$ 下方位， $3 \mathrm{~mm}$ 下方位 で測定した。チューインガム咀嚼では下顎雨が上 顎雨に対して滑走運動する率が高く，切歯部での 記録では $2 \mathrm{~mm}$ 前後の滑走があるといわれてい $ろ^{27)}$ 。側方滑走運動路の傾斜は図 21 より $40 \sim 60$ 度 であることから，咬頭嵌合位の $1 \mathrm{~mm}$ 下方位は閉 口路が歯面に誘導されてちょらど滑走に移る部位 に相当すると考光られる。また $3 \mathrm{~mm}$ 下方位は下 顎崡が上顎歯との間でチューインガムを圧し潰し ながら上昇する位置であり，また閉口位より霜の 影響から離れて開口し始める位置でもある。舌面 装置の装着により犬歯の舌面傾斜恃急になるが, それによって下顎の運動は制約されることにな る。片側で傾斜が10度急になったとすると, $1 \mathrm{~mm}$ 下方位では正中線との間の距離が $0.3 \sim 0.5 \mathrm{~mm}$ 程 度狭くなるはずである。ここでは咀嚼運動路の左 右幅径を測定したが, 舌面装置の装着により 6 被 験者中 5 例でそれが小さくなり，1〜2週後には 最小値を示し装置装着前との差では $0.5 \mathrm{~mm}$ 前後 小さくなっていた。これは明らかに犬歯舌面装置 が咀嚼運動路に影響を与えたことを示すものであ る。

咀嚼運動は上位中枢の支配を受けると同時に局 所からの刺激によっても制御されることはよく知 られている28)。よってここでの咀嚼運動路の変化 も単に犬歯の舌面の接触によって機械的に強いら れているだけではなく, 歯根膜を含む周辺受容器 からの刺激による神経筋機構を介した自動的な運 動の変化が起こったものと考兄られる。このこと は犬霜の舌面傾斜が関与しない $3 \mathrm{~mm}$ 下方位です でに運動路左右幅径の狭小が起こっていることか らも推測できる。つまり咀嚼運動路は犬歯舌面傾 斜が急になったことによって経時的にその左右幅 径が小さくなり，側方要素の少ない，いわゆる chopper type の形に変化していくようである。

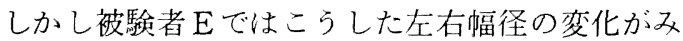
られなかったがここれは装置装着前の咀嚼運動路 それ自体が chopper type で舌面装置がほとんど 関与しなかったためと考光られる。

以上のごとく咀嚼運動路は犬歯舌面傾斜が急に
なることによってその幅が狭くなったが，装置装 着 $1 \sim 2$ 週後を境として再び徐々に幅径を増し, 約 3 週後には元の状態に戻ってしまら。この回復 現象は前項で述べた歯の変位量の変化の場合と同 様である。

（2）咀嚼運動路および歯の変位量の変化

咀嚼運動路の左右幅径の変化と犬歯の变位量の 変化とはほぼ同期しているようで，それぞれの頂 点に達する時期も大体一致していた。そこで両者 の関係をつぎのように検討してみた。まず，変位 量の代表として $500 \mathrm{~g}$ （M）を選び， その基準值 を 100 として舌面装置装着中および除去後に得ら れた変位量の基準値との差の割合を求めた。一 方, $1 \mathrm{~mm}$ 下方位および $3 \mathrm{~mm}$ 下方位の咀嚼運動 路の左右幅径についても同様に, 舌面装置装着中 および除去後に得られた左右幅径の基準值との差 の割合を求めた。その結果は図23に示すよらに被 験者 $\mathrm{A}, \mathrm{B}, \mathrm{C}, \mathrm{D}, \mathrm{F}$ では両者は浪ぼ平行し, 両者の間の相関係数を求めたところ高い相関性が みられ（表16）, 変位量の変化と咀嚼運動路の変 化の間には密接な関係があることがわかった。

また, 舌面装置装着 $1 \sim 2$ 週後から咀嚼運動路 および犬歯の変位量がともに回復する現象がみら れたが，これに関与する因子として歯自体の傾 斜，あるいは舌面装置や対咬歯の磨耗などがすず 考えられる。雪の傾斜については実験中に記録し た側方滑走運動路の形態，傾斜にほとんど変化 が認められなかったことから可能性は少ないで あろら。また，咬耗は当然起こると考兄られ， 舌面装置によって $1 \mathrm{~mm}$ 下方位 で左右的に 0.2 〜 $0.5 \mathrm{~mm}$ 狭くなったものがその分だけ徐々に 磨耗するとすればこうした回復現象は起こりら る。これる各側方滑走運動路を比較すればわかる ことであるが，明確な差異は認められなかった。 そこで咀嚼運動路について考えると, 測定した のは開口路, 閉口路の左右幅径であるので, 舌面 装置により閉口路が側方的に制約されたとしても 開口路の側方要素がより大きくなれば両者間の距 離，つまり左右幅径は大きくなるはずである。一 般に咀嚼運動路は閉口路が咀嚼側に突桳した形を 

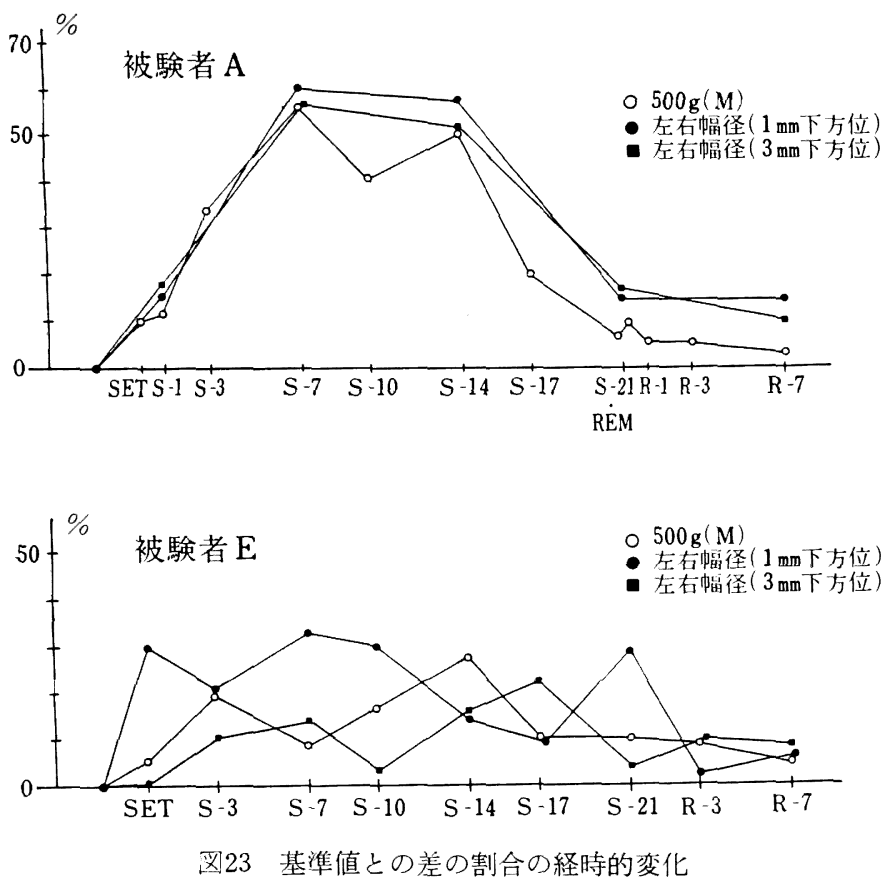

表16 基準値との差の割合について， $1 \mathrm{~mm}$ 下方位および $3 \mathrm{~mm}$ 下方位での 左右幅径と $500 \mathrm{~g}$ (M) との相関倸数

\begin{tabular}{l|c|c|c|c|c|c}
\hline \hline 被 験 者 & $\mathrm{A}$ & $\mathrm{B}$ & $\mathrm{C}$ & $\mathrm{D}$ & $\mathrm{E}$ & $\mathrm{F}$ \\
\hline $1 \mathrm{~mm}$ 下方位 & 0.973 & 0.950 & 0.921 & 0.962 & 0.390 & 0.863 \\
$3 \mathrm{~mm}$ 下方位 & 0.934 & 0.978 & 0.874 & 0.948 & 0.226 & 0.944
\end{tabular}

描き, 開口路は種々であるが側方要素は比較的 少ない傾向がある。閉口路が制約されて chopper type に変わっていき，それまで上下的であった 開口路が非咀嚼側に向かって突弯する形に変わっ ていったとすれば，左右幅径のある時点からの回 復は説明がつくことになる。そこで, 咀嚼運動路 の左右幅径の最も大きな変化を示した被験者 Dの 各咀嚼ストロークを閉口路と開口路に分けて検討 すると, 舌面装置装着により開口路に変化はない が勗嚼側に突弯している閉口路が徐々に狭まり左 右幅径は減少する。装置装着10日以降では閉口路 はそのままで開口路が非咀嚼側へ徐々に広がり, 装置除去後でも装着前と比べて運動路全体が平衡 側へ傾いた感じになった(図24)。他の被験者では
左右幅径の変化が僅小であるため $(0.3 \sim 0.5 \mathrm{~mm})$ 判断し難いが，同様の傾向を示すものと推測され る。

こうした運動路の変化が犬歯の変位に影響を及 ぽし，舌面装置を介して加兄られる犬歯への側方 力が軽減するため歯の変位量もこれと平行して減 少したものと考えられるが，詳細はさらに検討が 必要である。

\section{V. 結論}

下顎運動の誘導に関する検討の1つとして, 犬 歯誘導咬合, group-functioned 咬合を有する被 験者の上顎犬歯に舌面装置を装着して傾斜を急に しそれによる犬歯の荷重時の変位および咀嚼運 


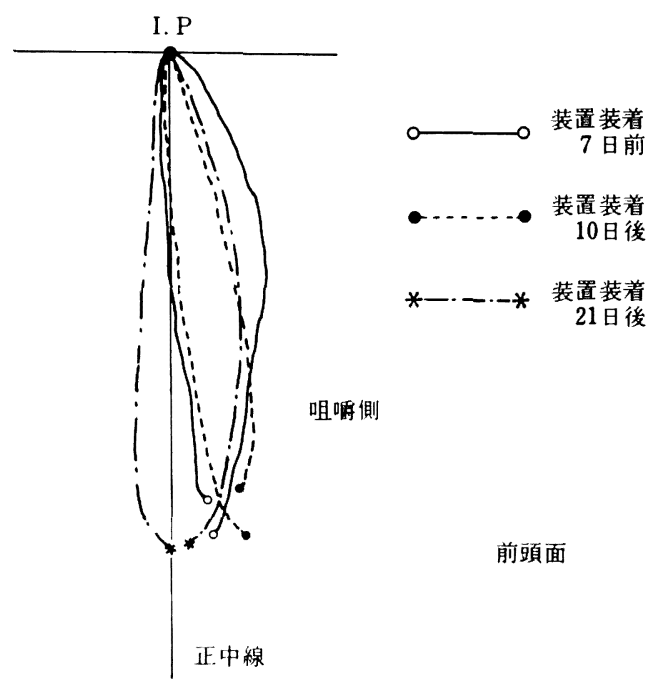

図24チューインガム咀嚼運動路の推移（被験者D）

動路に及ぽす影響を経時的に記録し 検討した結 果, 以下の結論を得た。

1. 舌側から荷重した際犬雨は頓側, 歯根方向 へ直線的な変位経路を示した。そこでこの変位経 路をべクトル化し距離を変位量, 賽側方向とのな す角を変位方向とした。

2. 被験霜の変位量は 6 被験者中 5 例で, 舌面 装置装着後除々に増加し装置装着 $1 \sim 2$ 週後で頂 点に達しその後徐々に減少し, 装置装着 3 週後お よび除去後では装置装着前とほぼ同じ值にまで回 復した。

3. 変位量の経時的変化を被験歯と対照崡で比 較すると, 上記の被験者では舌面装置装着 $1 \sim 2$ 週後の間で明らかに有意差がみられた。

4. 被験雪の变位量にみられた増加後減少する 変化傾向は初期動摇量の変化傾向と密接な関係が あった。

5. 荷重方向に関しては正確な規制を行わなか ったにもかかわらず，変位方向の值に大きな差異 はみられなかった。

6. 変位量の変化がみられた 5 被験者中 4 例で 変位方向の值も変位量と同様の変化を示し, 変位 量を煩側方向と歯根方向の移動距離に分けてその
経時的変化を観察すると，歯根方向移動距離は煩 側方向に比べ著明な变化傾向を示した。

7. 变曲点に扰ける荷重量は全被験者とも変化 しなかった。

8. チューインガム咀絪時の運動経路の咬頭嵌 合位より $1 \mathrm{~mm}$ および $3 \mathrm{~mm}$ 下方位の左右 幅径 は, 変位量の変化がみられた 5 被験者で舌面装置 装着後徐々に減少し, 装着 $1 \sim 2$ 週後で最小值を 示しその後徐々に増加し, 装置装着 3 週後打よび 除去後では装着前とほぼ同じ値を示した。

9. 舌面装置装着後にみられた被験歯の变位量 の変化之咀嚼運動路左右幅径の変化との間には密 接な関係があった。

\section{謝 辞}

稿を終えるにあたり，ご留篤なご指導とご校閲を賜 りました藍 稳教授に䔆んで感謝の意を表します。

また本研究に際し，ご援助，ご協力をいただきまし た第 1 歯科補経学教室の諸先生方, ならびに被験者の 皆様に心から扰礼申し上げます。

本研究の一部は昭和 58,59 年度文部省科学研究費補 助金 No, 57480361，No, 59480379 とよった。

\section{文献}

1) Schuyler, C. H. : Factors contributing to traumatic occlusion. J. Prosthet. Dent. 11 : 708$715,1961$.

2) Ramfjord, S. P. : Dysfunctional temporomandibular joint and muscle pain. J. Prosthet. Dent. $11: 353-374,1961$.

3）藍 稔: 顎機能異常, 咬合からのアプローチ. 東京, 1983, 医歯薬出版, 159-189.

4) D'Amico, A. : Functional occlusion of the natural teeth of man. J. Prosthet. Dent. $11: 899$ 915, 1961.

5) Guichet, N. F. (保母須弥也, 大矢政男, 永海 弘和訳): Occlusion, 東京, 1973, 医歯薬出版, $23-31$.

6) Hannam, A. G., Wood, W. W., De Cou, R. E. and Scott, J. D. : The effects of working-side occlusal interferences on muscle activity and associated jaw movements in man. Archs. oral Biol. 26 : 387-392, 1981.

7）土居 勗, 三谷春保 : 実験的犬歯誘導咬合が正 常顎機能者の咀嚼運動に及ほす影響について. （講演抄録）補綴誌 $26: 178-179,1982$. 
8) Mühlemann, H. R. : 10 years of tooth-mobility measurments. J. Periodontol. $31: 110-122$, 1960.

9）石橋真澄：歯牙の動摇に関寸る実験的研究（第 1 報），荷重と動摇との関係について. 口腔誌 $20: 187-191,1953$.

10) Heners, M. : Syndesmotic limiting movement of the periodontal ligament. Int. Dent. J. 24 : 319-327, 1974.

11）加藤 均: 歯周組織の機能状態に関する研究, 第 1 報, 2 次元徽小变位計. 補緅誌 $25: 733-$ $745,1981$.

12）五十風順正, 藍稔: 非接触微小変位センサ 一による米の動態観察, 第 1 報, 装置の概要と 测定方法. 補緅誌 $24: 457-469,1980$.

13) Behrend, D. A. : A method of studying patterns of tooth displacement in simulated chewing cycle in man. Archs. oral Biol. $19: 23-27$, 1974.

14）荻田訓久：非接触型三次元微小変位測定装置の 試作について。（講演抄録）補綴誌 $26: 866$, 1982.

15) Curilović, Z. : Einfluss der experimentellen Eckzahnführung auf die Zahnbeweglichkeit. SMfZ/RMSO $81:$ 413-433, 1971.

16) O'Leary, T. J., Shanley, D. B. and Drake, R. B. : Tooth mobility in cuspid guidance and $\mathrm{gr}$ oupe-function occlusion. J. Prosthes. Dent. $27: 21-25,1972$.

17) Hofmann, M. : Eckzahnführung und paradontale Reaction. Dtsch. Zahnärztl. Z. $29: 823-$ 826, 1974.

18）五十闽順正, 斉藤良一, 藍稔: 非接触微小 変位センサーによる歯の動態観察，第 2 報, 種
々の钼察例. 補緅誌 $25: 295-303,1981$.

19) Behrend, D. A. : Patterns of tooth displacement in simulated chewing cycle in man. Archs. oral Biol. 23 : 1089-1093, 1978

20) Mühlemann, H. R. : Tooth mobility (IV), Tooth mobility changes through artificial alterations of the periodontium. J. Periodontol. 25 : 198-202, 1954.

21) Mühlemann, H. R., Savdir, S. and Rateitschak, K. H. : Tooth mobility-It's causes and significance. J. Periodontol. $36: 58-63,1965$.

22) Mühlemann, H. R. and Herzog, H. : Tooth mobility and microscopic tissue changes produced by experimental occlusal trauma. Helv. Odont. Acta. 5 : 33-39, 1961.

23）石田哲彦，加藤 渠，本間 博，池野直人，石 川 純 : 外傷性咬合とくに早期接触による齿の 動摇度の変化に関する研究，(I) サルに拈ける 人工的早期接触の影響. (講演抄録) 日歯周誌 $18: 130-131,1676$.

24）田中伐平：咬頭嵌合位における補綴物の高さが 顎口腔系に及ぼす影響. 補経誌 $19: 666-692$, 1976.

25) Körber, K. : Elektronisches Messen der Zahnbeweglichkeit. Dtsch. Zahnärztl. Z. $16: 605$ 613, 1962.

26）斉藤良一：荷重時における歯の動態に関する研 究. 口病誌 $50: 568-587,1983$.

27）藍稔：切歯点部に扮ける咀嚼運動の解析. 補緅誌 $6: 164-200,1962$.

28) Thexton, A. J. : To what extent is mastication programmed and independent of peripheral feedback? ed. Anderson, D. J. and Matthews, B., Mastication, Bristol, 1976, Wright, 213-220. 